Article

\title{
The Clupeocephala re-visited: Analysis of characters and homologies
}

\author{
Re-evaluación de Clupeocephala: Análisis de caracteres y homologías
}

\author{
Gloria Arratia ${ }^{1,2}$ \\ ${ }^{1}$ Biodiversity Research Center, The University of Kansas, Dyche Hall, Lawrence, Kansas 66045-7561, U.S.A. garratia@ku.edu \\ ${ }^{2}$ Department of Geology, Field Museum of Natural History, Chicago, Illinois, U.S.A.
}

\begin{abstract}
Resumen.- Se revisan los caracteres que soportan la monofilia de la cohorte Clupeocephala -el clado más grande de Teleostei-. La re-evaluación de estos caracteres demuestra que: 1) varios de ellos no son únicos, contradiciendo interpretaciones previas, sino que son homoplasias que se presentan también en grupos ajenos a clupeocéfalos (e.g., tcrossognátidos y osteoglosomorfos), 2) otros están ausentes en clupeocéfalos basales, 3) algunos son variables en clupeocéfalos, 4) otros son, aparentemente, caracteres errados y 5) algunos de esos caracteres, en la forma en que fueron descritos, no son homólogos. El presente estudio muestra que la monofilia de Clupeocephala está soportada por varios caracteres que no son ambiguos. Tres de ellos son aparentemente caracteres derivados únicos (osificación temprana del autopalatino, arteria hioidea perforando el hipohial ventral, placa dentaria del último faringobranquial o cartilaginoso faringobranquial 4 resultan del crecimiento de una placa y no de la fusión de varias de ellas) y siete son homoplásticos pero son interpretados como adquiridos independientemente en cada uno de los linajes en que se presen$\tan$ (e.g., presencia de anguloarticular, retroarticular excluído de la faceta articular para el cuadrado, ausencia de placas dentarias en faringobranquial 1 y presencia de seis o menos hipurales). Un caracter previamente interpretado como una sinapomorfía de clupeocéfalos es propuesto como una posible sinapomorfía de euteleósteos (arco neural del centro ural 1 [terminología poliural] atrofiado o ausente). Además, los resultados obtenidos revelan la necesidad de más estudios morfológicos, ontogenéticos y filogenéticos que incluyan numerosas especies de elopomorfos, osteoglosomorfos y clupeocéfalos, tanto primitivos como avanzados, para entender el significado y distribución de los caracteres homoplásticos y testar aquellos que se consideran como únicos en la evolución de ciertos grupos de teleósteos.
\end{abstract}

Palabras clave: Peces, Teleostei, monofilia, sinapomorfias, homoplasias

\begin{abstract}
The characters supporting the monophyly of Clupeocephala are revised. The re-evaluation of these characters demonstrates that: 1) several characters as previously interpreted, are not unique, but homoplastic occurring elsewhere in non clupeocephalans (e.g., tcrossognathiforms and osteoglossomorphs); 2) other characters are absent in most basal clupeocephalans; 3) some are variably present in basal clupeocephalans; 4) other characters seem to be wrong; and 5) several characters as previously defined, represent ambiguous homologies. Nevertheless, the present study reveals that the monophyly of Clupeocephala is supported by several unambiguous characters. Three of them are, apparently, uniquely derived novelties (early ossification of autopalatine; hyoidean artery piercing ventral hypohyal; toothplate of last pharyngobranchial or pharyngobranchial cartilage 4 corresponds to growth of only one toothplate), and seven are homoplastic, but are interpreted here as independently acquired in the different teleostean subgroups where they occur (e.g., anguloarticular present; retroarticular excluded from articular facet for quadrate; toothplates on pharyngobranchial 1 absent; six or fewer hypurals present). One character previously interpreted as a clupeocephalan synapomorphy (neural arch of ural centrum 1 [polyural terminology] reduced or lost) is proposed as a euteleostean synapomorphy. Additionally, the results reveal the need for further developmental, morphological, ontogenetic and phylogenetic studies, including many basal and advanced elopomorph, osteoglossomorph, and clupeocephalan species, to understand the meaning and distribution of the homoplastic characters and to test those interpreted as unique novelties of teleostean subgroups.
\end{abstract}

Key words: Fishes, Teleostei, monophyly, synapomorphies, homoplasies

\section{INTRODUCTION}

The teleostean cohort Clupeocephala is an extant fish group erected by Patterson \& Rosen (1977) to contain the subcohorts Clupeomorpha (e.g., engraulids, clupeids) and Euteleostei (e.g., catfishes, salmonids, galaxiids, atherinids, percoids) (Fig. 1). The current interpretation of the
Clupeocephala, however, includes the subcohorts Ostarioclupeomorpha (Arratia 1996a, 1997) or Otocephala (Johnson \& Patterson 1996) (ostariophysans plus clupeomorphs; see Nelson 2006, p. 127) and Euteleostei (Fig. 2). This new hypothesis that includes the 
ostarioclupeomorphs as sister to the euteleosts is supported by morphological (e.g., Johnson \& Patterson 1996, Arratia 1997, 1999) and molecular (e.g., Inoue et al. 2001) evidence, but see Li et al. (2008; Fig. 3), where the cohort Clupeocephala appears in an unresolved position along with elopomorphs (non-monophyletic) and osteoglossomorphs.

The Clupeocephala is the largest group among Teleostei because it includes most teleosts (Fig. 4) with the exception of elopomorphs, osteoglossomorphs, and extinct $(\dagger)$ basal teleosts belonging to groups such as the †Leptolepididae, the $†$ Crossognathiformes (previously considered a clupeoceplahan group by Taverne 1989, but recently interpreted as a basal teleostean clade by Arratia 2008a), and the †Ichthyodectiformes.

The large group Clupeocephala has a long evolutionary history that can be traced back to the Upper Jurassic of Europe -about 153 million years ago- with fossil taxa such as †Leptolepides, †Orthogonikleithrus, and †Tischlingerichthys (Arratia 1997: figs. 39, 40, 49, 50, 55, 56). However, Peng et al. (2006) recent molecular studies proposed the varying ages of divergence of 307 million years (Paleozoic: Carboniferous) for the clupeocephalans and of 282 million years (Paleozoic: Permian) for the ostarioclupeomorphs.

The name Clupeocephala was used first by Greenwood (1973) for clupeomorphs only. The creation of the cohort Clupeocephala was based on five characters (Patterson \& Rosen 1977: 126). Later, Taverne (1989) and Arratia (1997, 1999, 2008a) modified, added and/or deleted a few characters. Arratia $(1997,1998)$ discussed these characters and demonstrated that some of them are not unique to Clupeocephala or represent incorrect observations (see "Analysis of characters"). An additional problem is that the inclusion of certain fossils -e.g., †crossognathiforms-and new information on extant fishes change the interpretation of a few characters previously thought to be as uniquely derived clupeocephalan synapomorphies (Arratia 2008a, see below). The main problem involving several of these characters is that they are based on conflicting or assumed homologies where a common ancestry has been assumed or they represent a homology hypothesis that is unsupported by a phylogeny (see comments in Arratia 1998, 2004), an issue that is not unique to clupeocephalans, but a shortcoming of many characters supporting different phylogenetic levels of actinopterygians (see comments in Schultze \& Arratia 1989, Arratia \& Schultze 1991, 1992, Arratia 1996b, 1999, 2004, 2008b, Cloutier \& Arratia 2004, Schultze 2008, Wiley 2008).
Within the frame of the Tree of Life project "Collaborative Research: Systematics of Cypriniformes, Earth's Most Diverse Clade of Freshwater Fishes", I have had the opportunity to study day-to-day ontogenetic series of cypriniforms, other ostariophysans, clupeomorphs and basal euteleosts and discovered that some characters that are currently interpreted as clupeocephalan synapomorphies are not present in some of the basal clupeocephalans or have conflicting interpretations. The main goal of this contribution is to re-evaluate the clupeocephalan characters in light of new data and to propose an emended characterization of the group. To fulfill this goal, the study is focused at the basal clupeocephalan level (e.g., Clupeomorpha, Ostariophysi, Protacanthopterygii) and includes evidence of both fossil and extant fish groups. It is accepted here that some of the clupeocephalan characters may have been lost in more advanced forms.

\section{Material AND Methods}

Most of the extant fishes included in this study are cleared and stained (cl\&st) for both cartilage and bone following a procedure described in Arratia \& Schultze (1992). Others are prepared as dry skeletons (skl). Some of the fossil $(\dagger)$

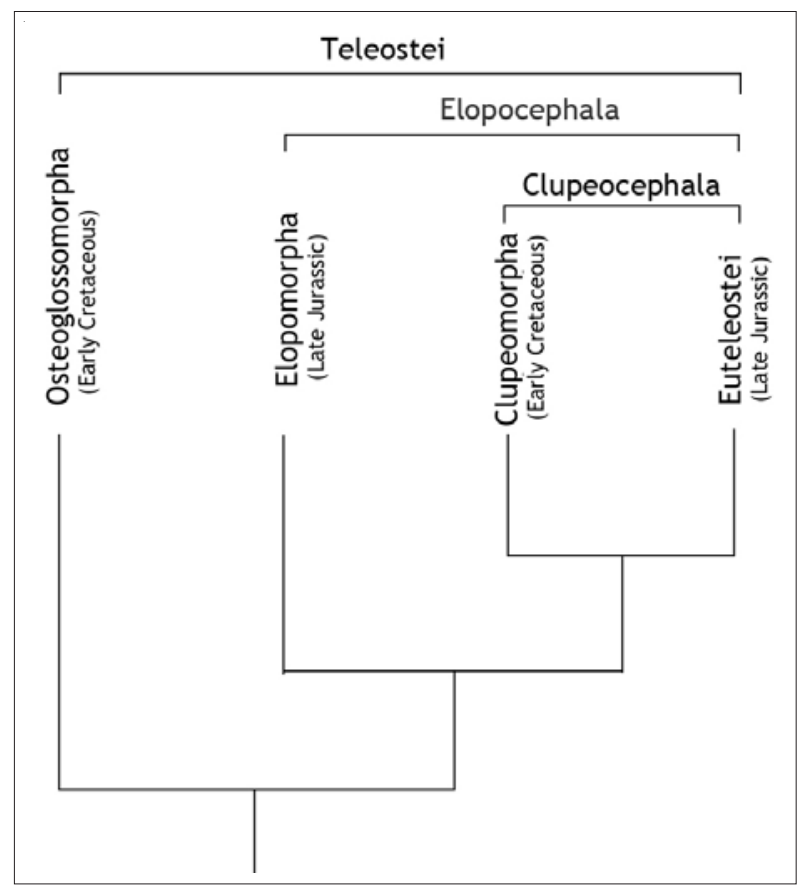

Figure 1. Phylogenetic hypothesis of teleostean relationships (crown group) after Patterson \& Rosen (1977), based on morphological characters. Ages of oldest fossils of each lineage are added / Hipótesis de relaciones filogenéticas de teleósteos (crown group) según Patterson \& Rosen (1977), basada en caracteres morfológicos. Se agrega la edad de los fósiles más antiguos 
fishes were mechanically prepared, whereas others were acid prepared according to the technique described in Toombs \& Rixon (1959). Most of the studied material has been prepared by the author. The ontogenetic series of Cycleptus elongatus was cleared and stained [by J. Engeman (University of South Dakota, Vermillion)]. Small specimens were studied and photographed under an Olympus ${ }^{\circledR}$ microscope with normal optic, face contrast and polarized light with a Nikon ${ }^{\circledR}$ camera attachment. Larger specimens were studied under a Leica ${ }^{\circledR}$ MZ9 stereomicroscope with both a Leica digital camera attachment and camera lucida attachment. The size of the specimens is given only for the extant material (SL: standard length; NL: notochordal length)

\section{INSTITUTIONAL ABBREVIATIONS AND SPECIMENS STUDIED}

The study includes a vast number of specimens deposited in different museums all over the world. Only the material that is mentioned and/or used in descriptions and illustrations is listed.

The studied material is catalogued in the following institutions: AMNH, American Museum of Natural History, New York, U.S.A.; ANSP, Academy of Natural Sciences, Philadelphia, Pennsylvania, U.S.A.; BGHan, Bundesanstalt

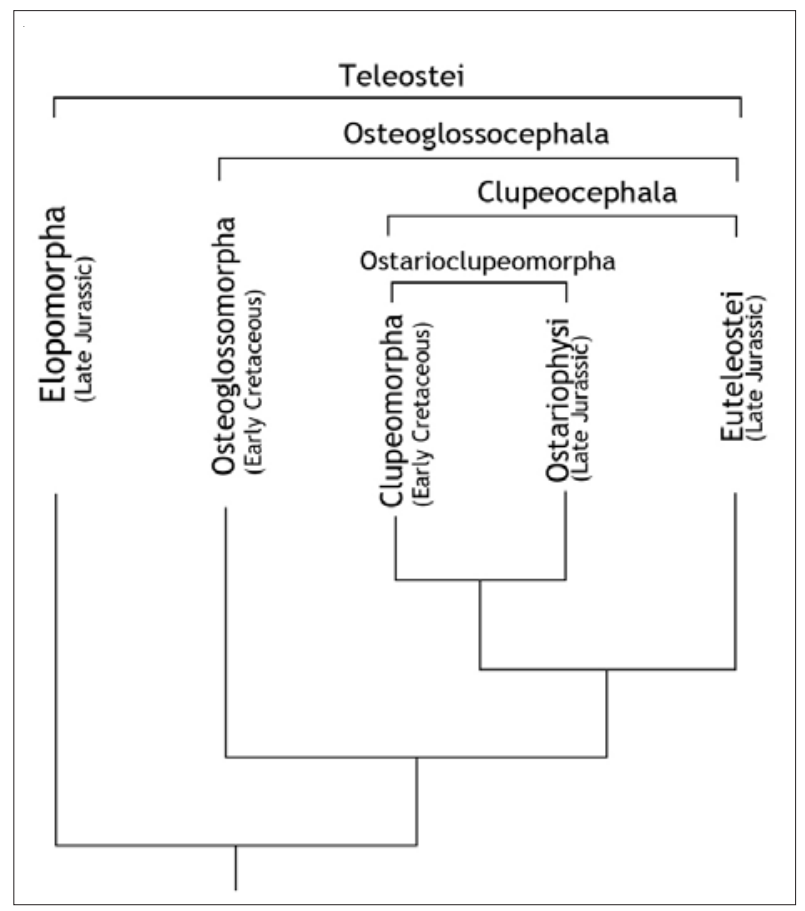

Figure 2. Hypothesis of teleostean relationships (crown group) after Arratia $(1997,1999)$ based on morphological characters / Hipótesis de relaciones filogenéticas de teleósteos (crown group) según Arratia (1997, 1999), basada en caracteres morfológicos für Geowissenschaften und Rohstoffe, Niedersächsisches Landesamt für Bodenforschung, Hannover, Germany; BSPG, Bayerische Staatssammlung für Paläontologie und historische Geologie, Munich, Germany; CAS, CAS(SU), California Academy of Sciences, San Francisco, California, U.S.A.; DMNH, Denver Museum of Natural History, Denver, Colorado, U.S.A.; FMNH, Field Museum of Natural History, Chicago, Illinois, U.S.A.; GOE, Institut und Museum für Geologie und Paläontologie, GeorgAugust Universität, Göttingen, Germany; JFBM, James Ford Bell Museum - Ichthyology Collection, Saint Paul, Minnesota; JME, Jura Museum, Naturwissenschaftliche Sammlungen, Eichstätt, Germany; KUMNH, University of Kansas, Natural History Museum, Division of Fishes, Lawrence, Kansas, U.S.A.; KUVP, University of Kansas, Natural History Museum, Division of Vertebrate Paleontology, Lawrence, Kansas, U.S.A.; LBUCH, Laboratorio de Biología, Universidad de Chile, Santiago, Chile (all of these specimens will be deposited in the Museo Nacional de Historia Natural, Santiago, Chile); LACM, Division of Paleontology, Los Angeles County Museum, Los Angeles, U.S.A.; MB, Collection of Fossil Fishes, Museum für Naturkunde der Humboldt Universität, Berlin, Germany; MCSNB, Museo Civico di Scienze Naturali "Enrico Caffi", Bergamo, Italy; MCZ, Museum of

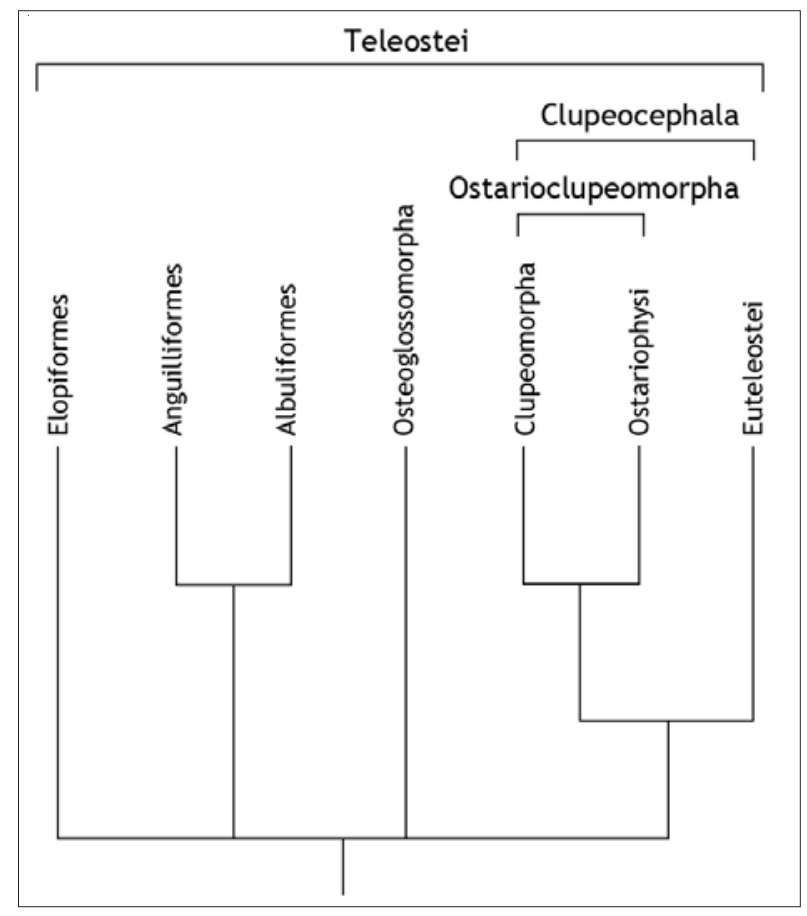

Figure 3. Hypothesis of teleostean relationships (crown group) after Li et al. (2008) based on molecular evidence / Hipótesis de relaciones filogenéticas de teleósteos (crown group) según Li et al. (2008) basada en evidencia molecular 


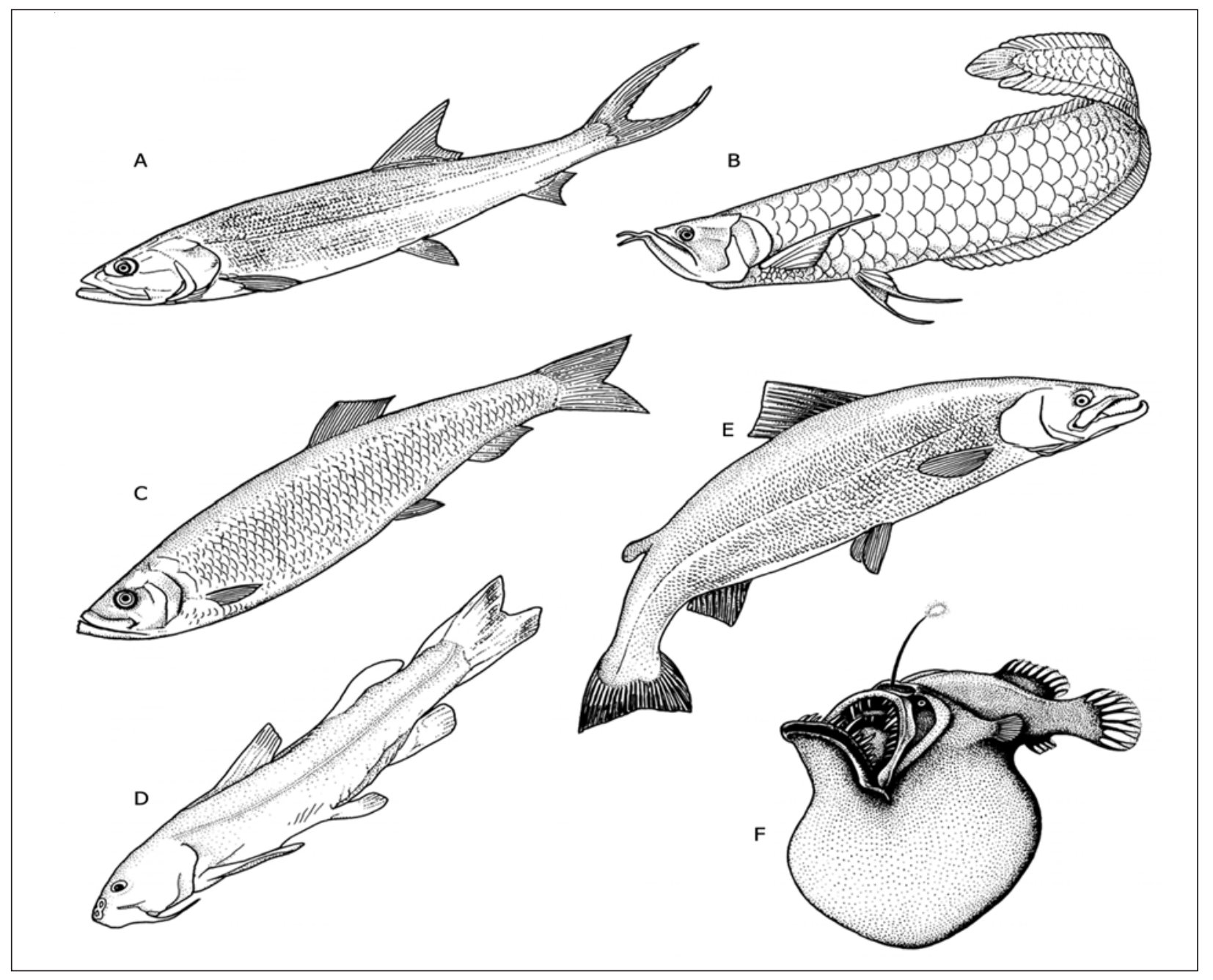

Figure 4. Diagrammatic representation of the main teleostean lineages such as elopomorphs (A), osteoglossomorphs (B) and clupeocephalans (C-F). Clupeocephalans are represented by clupeomorphs (C), ostariophysans (D), protacanthopterygians (E), and neoteleosts (F) (after Arratia 2000b) / Representacion diagramática de los linajes principales de teleósteos tales como los elopomorfos (A), osteoglosomorfos (B) y clupeocéfalos (C-F). Los clupeocéfalos están representados por clupeomorfos (C), ostariofisos (D), protacantopterigios (E) y neoteleósteos (F) (según Arratia 2000b)

Comparative Zoology, Harvard University, Cambridge, Massachusetts, U.S.A.; MNHN-Stgo., Museo Nacional de Historia Natural, Santiago, Chile; MRAC, Musée Royale de l'Afrique Centrale, Tervuren, Belgium; OS, Department of Fisheries and Wildlife, College of Agriculture Sciences, Oregon State University, Corvallis, Oregon, U.S.A.; Pi, Institut und Museum für Geologie und Paläontologie, Georg-August Universität, Tübingen, Germany; ROM, Royal Ontario Museum, Toronto, Canada; SIO, Scripps Institution of Oceanography, University of California, La Jolla, California, U.S.A.; Slg. Innsb.: Paläontologische Sammlungen, Universität Innsbruck, Austria; SMNH, Swedish Museum of Natural History, Stockholm, Sweden; SMNS, Staatliches Museum für Naturkunde, Stuttgart,
Germany; TCWC, Texas Cooperative Wildlife Collection, Department of Wildlife and Fisheries Science, Texas A\&M University, College Station, Texas, U.S.A.; TU, Tulane Museum, New Orleans, U.S.A.; UAVP, University of Alberta, Laboratory of Vertebrate Paleontology, Alberta, Canada; UCLA, Department of Biology, University of California at Los Angeles, Los Angeles, U.S.A; UF, Florida Museum of Natural History, Florida, U.S.A; UNC, University of North Carolina, Institute of Marine Sciences, Morehead City, North Carolina, U.S.A.; UMMZ, University of Michigan, Museum of Zoology, Ann Arbor, Michigan, U.S.A. and USNM, United States National Museum, Smithsonian Institution, Washington D.C., U.S.A. 


\section{SPECIMENS STUDIED}

†"Pholidophoriformes": †Eurycormus speciosus: BSPG AS V510 and BSPG 1960 XVIII 106; JM SOS 2339 and JM SOS 2341. †Pholidophorus bechei: FMNH 2137, MB f. 3504, and SMNS P 944. †Pholidophorus latiusculus: MCSNB 4302, MCSNB 4303b, MCSNB 4346a, and MCSNB 4723; Slg. Innsb 115. †Siemensichthys macrocephalus: BSPG AS I 1134; JME SOS 2812; MB. f.7007 and MB. f.7008a, MB. f. 7008b.

†Leptolepididae: †Leptolepis coryphaenoides: BGHan 1931-4, BGHan 1956-8, BGHan 1957-2, BGHan 1957-5, and BGHan 1960 (acid prepared specimens); GOE uncat., many disarticulated specimens; SEM preparation of many disarticulated bones.

†Crossognathiformes: †Chongichthys dentatus: LBUCH 021778a, LBUCH 021778b, LBUCH 15-010277a, and LBUCH 15-010277b. †Domeykos profetaensis: LBUCH 12-260972a, LBUCH 12-260972b, LBUCH 01277-13a, and LBUCH 01277-13b. †Protoclupea atacamensis: LBUCH 1-250277a. †Protoclupea chilensis: R-396a, R396b; LBUCH 190179a and LBUCH 190179b. †Varasichthys ariasi: LBUCH 16-260972a, LBUCH 16260972b, LBUCH 012378a, LBUCH 020778a, and LBUCH 020778b.

†Ichthyodectiformes: †Allothrissops mesogaster: JME SOS 1941/17a; FMNH-PF UC 2021 and FMNH-PF UC 2082; SMNH P 976, SMNH P 2925, and SMNH P 7733. †Pachythrissops propterus: BSPG 1986 XXIII 154; JME SOS 741; MB. f. 3505. †Thrissops cf. †T. formosus: JME SOS 3024. †Thrissops subovatus: JME SOS 1953/14a. †Thrissops cf. T. subovatus: JME SOS 2557.

\section{ELOPOMORPHA}

†Anaethalion angustus: JME SOS 2271, JME 2259, JM SOS 2260, JM SOS 2261a, and JM SOS 2261b. †Anaethalion angustissimus: JME SOS 2271, Pi F 891, Pi 1074/1, Pi 1074/2, and PiY 1930. †Anaethalion knorri: JME SOS 2267a, JM SOS 2267b, JME SOS 2270, and JM SOS 2282.

Albula vulpes: AMNH 56840, skl, \pm 292 mm SL; AMNH 56743, skl, $\pm 300 \mathrm{~mm} \mathrm{SL}$; and AMNH 56878, skl, \pm 305 mm SL; UCLA W58-96, 2 cl\&st, 195 and 220 mm SL; UCLA W49-122, 5 cl\&st, 46.7, 54.6, 63.5, 72.7, and 88.8 mm SL; UCLA W 49-122, 4 cl\&st, leptocephalous larvae. Anguilla rostrata: KUMNH 5029, 6 cl\&st, 50, 50.4, 53.8, 55, 82.5, and $103 \mathrm{~mm}$ SL. Elops affinis: SIO 69-167, 1 cl\&st, 121 mm SL; UCLA W 50-29, 4 cl\&st., 121.3, 128.4,
157, and 165 mm SL. Elops hawaiensis: CAS(SU) 35105, partially disarticulated skl, braincase of about $90 \mathrm{~mm}$ length; OS 5105, 2 cl\&st leptocephalous larvae, 26.7 and $32.5 \mathrm{~mm}$ SL. Elops saurus: ANSP 147401, 2 cl\&st, 97.8 and 99.1 mm SL; CAS(SU) 10847, skl, \pm 395 mm SL; TCWC 0503.1, 5 cl\&st, 24.0, 24.0, 26, 30.0, and $35.0 \mathrm{~mm} \mathrm{SL;} \mathrm{TCWC}$ 0782.1, 3 cl\&st., 35.7, 43, and 46.4 mm SL; TCWC 2452.2, 5 cl\&st, 60.1, 97.3, 107, 110,4 and 154 mm SL; UF 20180, head skl, braincase about 70 mm length; UMMZ 189366, partially disarticulated skl, braincase $71 \mathrm{~mm}$ length. UNC 82/8, 2 cl\&st, 57 and 76 mm SL. Megalops atlanticus: AMNH 211541 head only, skl, braincase about $255 \mathrm{~mm}$ length and AMNH 211544 head only, skl, braincase about 190 mm length; UF 208605, 4 cl\&st; UF 171286, 5 cl\&st, 26.3, 27.8, 29.1, 29.8, 40.5 mm SL; UF 208605, 5 cl\&st, 25.5, 31, 32.7, 41.1, and $44.5 \mathrm{~mm} \mathrm{SL}$; UF 208780, 3 cl\&st, 85, 90.4, and $122.5 \mathrm{~mm}$ SL. Megalops cyprinoides: CAS 35104, skl., \pm 460 mm SL; CAS 145216, 2 cl\&st, 17.5 mm and $34.5 \mathrm{~mm}$ SL.

\section{OSTEOGLOSSOMORPHA}

†Lycoptera davidi: LACM 4959-122316 and LACM 4959122317; SMNH P 6553. †Lycoptera cf. L. sinensis: FMNH 1291a and FMNH 1291b. Hiodon alosoides: JFBM 43312, $1 \mathrm{skl}, \pm 400 \mathrm{~mm}$ SL; JFBM 43306, $1 \mathrm{skl}, \pm 380 \mathrm{~mm}$ SL; KUMNH 7618, 7 cl\&st, from 22.0 to $56.0 \mathrm{~mm} \mathrm{SL}$; KUMNH 9618, 7 cl\&st, between 22 to 55 mm SL; KUMNH 3 cl\&st, 68, 70, and 72 mm SL; KUMNH 9661, 2 cl\&st, 59 and $67 \mathrm{~mm}$ SL; KUMNH 13993, 2 cl\&st, 200 and 305 mm SL. Hiodon tergisus: KU 9662, 3 cl\&st, 48.6, 51.8, and 55.7 mm SL. Osteoglossum ferrerai: KUMNH 22650, 1 cl\&st, 52.3 mm SL. Pantodon buchholzi: KUMNH 22651, 1 cl\&st, 50 mm SL.

\section{Clupeocephala}

Clupeomorpha: Alosa chrysochloris: KUMNH 9634, 2 cl\&st, 43.7 and $54.3 \mathrm{~mm}$ SL. Anchoa mitchilli: KUMNH 7494, 2 cl\&st, disarticulated specimens; KUMNH 17183, 2 cl\&st, disarticulated specimens. Brevoortia patronus: KUMNH 15113, 5 cl\&st, disarticulated specimens. Coilia nasus: KUMNH 40362, 33 cl\&st (15 larvae between 10.2 and $22.7 \mathrm{~mm}$ SL; 9 between 16.6 and $30.1 \mathrm{~mm} \mathrm{SL;} 9$ specimens between 63.5 and $103.1 \mathrm{~mm}$ SL). Denticeps clupeoides: MRAC M.T. 76-32-P-4915-932, 1 cl\&st, 29.1 mm SL; MRAC M.T. 76-44-P-7, 1 cl\&st, 18.5 mm SL. Dorosoma cepedianum: KUMNH 12100, 3 cl\&st, 30.5, 67, and $71.6 \mathrm{~mm}$ SL; KUMNH 16167, 1 cl\&st, 46.9 mm SL; KUMNH 21801, 169 cl\&st (100 sps. from 8 mm notochordal length (NL) to $15 \mathrm{~mm} \mathrm{SL}$ and $69 \mathrm{sps}$. from 
13.9 to $29.5 \mathrm{~mm}$ SL). Dorosoma petenense: KUMNH 956994, 2 cl\&st, 27.3 and 34.5 mm SL. Engraulis ringens: KUMNH 19347, 10 cl\&st, disarticulated specimens. Ethmidium maculatus: KUMNH 19349, 2 cl\&st, disarticulated large specimens. Jenkinsia lamprotaenia: KUMNH 40364, 10 cl\&st, from 34.5 to $49.1 \mathrm{~mm}$ SL. Lile stolifera: KUMNH 5411, 3 cl\&st, 29.5, 45.6, and $52.2 \mathrm{~mm}$ SL; UCLA 58-307, 3 cl\&st, 71.7, 80, and $88.1 \mathrm{~mm}$ SL. Sardinops sagax: KUMNH 19345, 6 cl\&st larvae, 14 to 19 $\mathrm{mm}$ SL, and $4 \mathrm{cl} \& s t$ disarticulated large specimens.

Ostariophysi: †Tischlingerichthys viohli: JME Moe 8. Aspius aspius: ROM 52742, 4 cl\&st, 26.7, 35.8, 51.8, and 59.8 mm SL; NRM 56968, 5 cl\&st, 34.6, 39.8, 46.9, 49.3, and 50.3 mm SL. Astyanax sp.: KUMNH 20099, 6 cl\&st, between 19.9 and $18.8 \mathrm{~mm}$ SL. Barbatula barbatula: ROM 49713, 5 cl\&st, 49.8, 60.9, 64.1, 66, and 75 mm SL. Brycon argenteus: KUMNH 10543, 2 cl\&st, disarticulated bones. Carpiodes carpio: KUMNH 21807, 24 cl\&st, 13.3 to 42.3 mm SL. Carpiodes microstomus: FMNH 35171, 4 cl\&st, 34.8, 38.8, 40.5, and $45.7 \mathrm{~mm}$ SL. Catostomus commersoni: JFBM 11495, 7 cl\&st, from 22.3 to $31 \mathrm{~mm} \mathrm{SL;} \mathrm{JFMB}$ 41727, skl, \pm 278 mm SL; KUMNH 38655, +100 cl\&st, between 12 to $21.3 \mathrm{~mm}$ SL. Chanos chanos: CAS(SU) 35075, 1 skl, disarticulated, braincase of $148 \mathrm{~mm}$ length; KUNHM 39848 to 39894, day-to-day series of about 200 specimens from about $4 \mathrm{~mm}$ to $10 \mathrm{~mm} \mathrm{NL}$ and from 7.0 to 83.5 mm SL; KUMNH 40365, 2 skl, 370 and 376 mm SL and $4 \mathrm{cl} \& s t, 150,180,330$, and $400 \mathrm{~mm}$ SL. SIO 80-199, 7 cl\&st, from 16.1 to $44.5 \mathrm{~mm}$ SL. Chanodictis mongolicus: USNM, 2 cl\&st, 112.6 and $136 \mathrm{~mm}$ SL. Cobitis lutheri: KUMNH 38976, 2 cl\&st, 55.6 and 81.5 mm SL. Cycleptus elongatus: KUMNH 40695, 1 cl\&st, 148 mm SL; TU 200816, day to day ontogenetic series, 13 cl\&st studied here, between 7.1 to $20.8 \mathrm{~mm}$ SL. Cyprinus carpio: FMNH 42392, 1 cl\&st, 85.5 mm SL; KUMNH 3739, 1 cl\&st, 80.0 mm SL; JFMB, skl, \pm 354 mm SL. Danio rerio: KUMNH uncat., 10 cl\&st; KUMNH 40245, day-to-day ontogenetic series of about 100 specimens, between 9 to $27.9 \mathrm{~mm}$ SL. Diplomystes nahuelbutaensis: MNHN-Sto uncat., 4 cl\&st, 150 to 180 mm SL. Diplomystes viedmensis: FMNH 58004, 2 cl\&st, 80.5 and $91.7 \mathrm{~mm}$ SL. Gonorynchus abbreviatus: CAS 30993, 1 cl\&st, 150 mm SL; FMNH 76476, disarticulated specimen. Hemiculter leuciscus: MCZ 32394, 2 cl\&st, 90.8 and $97.2 \mathrm{~mm}$ SL. Labeo batesi: USNM 303704, 4 cl\&st, 89.7, 95, 195.5, and $197.4 \mathrm{~mm} \mathrm{SL}$. Lepidomeda mollispinus: KUMNH 11768, 20 cl\&st, from 54.8 to $68.7 \mathrm{~mm}$ SL. Misgurnus anguillicaudatus: FMNH 57343, 5 cl\&st, 47, 50.1, 50.7, 53, and 80.5 mm SL; KUMNH 21447, 2 cl\&st, 96.2 and 100.3 mm SL. Notropis atherinoides: FMNH 72149, 20, cl\&st, from 20.2 to 55.5 mm SL. Noturus exilis: KUMNH 17229a, 10 cl\&st larvae, from 12.0 to $10 \mathrm{~mm}$ SL. Opsariichthys bidens: CAS(SU) 32512, 2 cl\&st, 81.9 and $117.6 \mathrm{~mm}$ SL. Opsariichthys uncirostris: KUMNH 21448, 4 cl\&st, 25, 29.6, 36.6, and 70.4 mm SL. Parabramis pekinensis: USNM 86494, 5 cl\&st, 49, 50.5, 54.7, 58.5, and $59.1 \mathrm{~mm}$ SL. Sabanajewa balcanica: FMNH 63814, 3 cl\&st, 33.9, 36.8, and 58 mm SL. Semonotilus atromaculatus: KUMNH 12594, $5 \mathrm{cl} \& s t$, 39, 41, 42, 42, 45, and $47 \mathrm{~mm}$ SL. Squalibarbus curriculus: AMNH 10890, 2 cl\&st, 112.6 and 136 mm SL. Xenocharax spilurus: CAS(SU) 15639, 2 cl\&st, 74.7 and $92 \mathrm{~mm}$ SL. Only a few cypriniforms are listed here from more than 150 species with cl\&st specimens included in the Tree of Life of Cypriniformes.

Euteleostei: †Erichalcis arcta: UAVP 8598, UAVP 8602, UAVP 8606, and UAVP 8612. †Humbertia sp.: DMNH 2518-1. †Leptolepides haerteisi: JME SOS 2473, JM SOS 2474, and JME SOS 2554. †Leptolepides sprattiformis: FMNH-PF 10984 and FMNH-PF 10986; JME SOS 2956; KUVP 60722 and KUVP 96128; SMNH P 1891, SMNS P 1894, SMNS 55106, and SMNS 55928. †Orthogonikleithrus hoelli: JME SOS 2301, JME SOS 2632, JME SOS 3954, JME SOS 3955, and JME 3956. †Orthogonikleithrus leichi: JME SOS 2301 and JM SOS 2632. †Orthogonikleithrus sp.: JME ETT 30 and JME ETT 216. Argentina sialis: SIO 66-4, 3 cl\&st, 119, 140, and 121.2 mm SL. SIO CR 5208, 4 cl\&st, 3 larvae of 9.0 to $14 \mathrm{~mm}$ NL, and $1 \mathrm{sp} .13 .5 \mathrm{~mm}$ SL. Esox americanus: KUMNH 17864, 4 cl\&st, 82.7, 89.5, 112, and 123 mm SL. Esox lucius: KUMNH 19092, disarticulated skl, lower jaw 120 mm length. Esox niger: KUMNH 21374, disarticulated skl, braincase $63 \mathrm{~mm}$ length. Oncorhynchus mykiss: KUMNH 12463, 7 cl\&st, from 28.0 to 43 mm SL; KUMNH 21936, 20 cl\&st, 290 to $300 \mathrm{~mm}$ SL; OS uncat., day-to-day ontogenetic series of about 200 cl\&st, from 13 $\mathrm{mm}$ NL to $73 \mathrm{~mm}$ SL. Prosopium cilindraceous: KUMNH 15471, 2 cl\&st, 300 and $310 \mathrm{~mm} \mathrm{SL}$. Prosopium williamsoni: KUMNH 11817, 13 cl\&st, 12 larvae between 20 and $33.6 \mathrm{~mm}$ SL and $1 \mathrm{sp}$. of $230 \mathrm{~mm}$ SL. Thymallus arcticus: KUMNH 15419, 3 cl\&st, 151, 166, and 177 mm SL. For other salmonids see list of material in Arratia \& Schultze (1992). Umbra limi: KUMNH 10370, 6 cl\&st, 22.5, 26.3, 27, 27.8, 52, and $54.4 \mathrm{~mm}$ SL.

\section{Results}

\section{Analysis of Characters}

The morphological characters are presented according to body regions. A short introduction of each character is presented first. A description and analysis of the character 
follows, ending in a new interpretation and evaluation where necessary.

\section{Palatoquadrate}

"Autopalatine bone ossifies early in ontogeny" (Arratia \& Schultze 1991, Arratia 1999, 2008a).

As far as it is known, the autopalatine bone begins to ossify in the pars autopalatina of the palatoquadrate cartilage early in ontogeny in all clupeocephalans where the early development of bones is known. For instance, in the gonorynchiform Chanos chanos the bone appears as a thin perichondral ossification at about $15.5 \mathrm{~mm}$ SL and from that moment on it ossifies very quickly (Fig. 5A; Arratia 1992: fig. 4B; Arratia \& Bagarinao 2009, p. 88, fig. 3). In the cyprinid, Danio rerio, the autopalatine begins to ossify at $7.6 \mathrm{~mm}$ SL (Cubbage \& Mabee 1996). In another cyprinid, Barbus barbus, the autopalatine begins to ossify at about $14 \mathrm{~mm}$ SL (Vandewalle et al. 1992). The bone is ossified at $25 \mathrm{~mm} \mathrm{SL}$ in the cyprinid Opsariichthys uncirostris (KUMNH 21448). In the catostomid Catostomus commersoni the autopalatine begins to ossify at $15.9 \mathrm{~mm}$ SL and the ossification invades the cartilage and also spreads away from the cartilage around its anterior end at $19.6 \mathrm{~mm}$ SL (Engenman et al. 2009). In another catostomid, Cycleptus elongatus, the ossification of the autopalatine begins earlier and in specimens around $15 \mathrm{~mm}$ SL the bone is almost completely ossified at its middle region (TU 200816; Fig. 5B). In the siluriform Diplomystes camposensis, the autopalatine is partially ossified at $23 \mathrm{~mm}$ $\mathrm{SL}$; it is almost completely ossified at $28 \mathrm{~mm}$ SL (Arratia 1992: fig. 16A-C). In Ictalurus punctatus the autopalatine begins to ossify at $11.7 \mathrm{~mm} \mathrm{SL}$, and in specimens of 14$14.5 \mathrm{~mm}$ SL the bone is almost totally ossified (Arratia 1991, p. 50-51). In Noturus exilis the autopalatine is ossified in specimens of $13.6 \mathrm{~mm}$ SL (Arratia 1992, p. 51, fig. 32A). In the perciform Sparus aurata the autopalatine begins to ossify at $7.4 \mathrm{~mm}$ SL (Faustino \& Power 2001). Similar observations have been obtained from a variety of clupeocephalans, such as the esociform Esox (Jollie 1984), the salmonid Oncorhynchus mykiss, the clupeomorphs Coilia nasus and Dorosoma cepedianum (Fig. 5C), the perciforms Percichthys and Percilia (pers. obser.), Dentex dentex (Koumoundouros et al. 2000), and Lates calcifer (Kohno et al. 1996). In contrast, the autopalatine begins to ossify late in ontogeny (juveniles / subadults) (Fig. 5D-F) in more basal fishes where the development is known, e.g., Amia calva (Arratia \& Schultze 1991, Grande \& Bemis 1998). Even in large specimens the bone is mainly a chondroid element or a hard fibrocartilage. The autopalatine is represented mainly by cartilage and begins to ossify in specimens of about $90 \mathrm{~mm}$ SL in Elops (Arratia \& Schultze 1991: 23-24; Fig. 5E, F herein). In large specimens of elopiforms (e.g., Elops saurus, Megalops cyprinoides) and albuliforms (e.g., Albula vulpes), the autopalatine is composed of a thin superficial ossification surrounding a mass of cartilage and chondroid bone in different stages of ossification. Osteoglossomorphs lack an autopalatine ossification (e.g., Taverne 1977, Arratia \& Schultze 1991, Hilton 2002), with a few exceptions such as Heterotis niloticus and Scleropages leichardti (other species of Scleropages lack an autopalatine; Ridewood 1905, Taverne 1998).

This character is poorly known for fossils due to preservation conditions (e.g., lack of preservation of cartilage or other soft tissues, or the palatine region may be covered by lateral bones such as maxilla, antorbital, and first infraorbital bone). Although, early developmental stages of fossil clupeocephalans are available (e.g., many young specimens of the euteleosts $†$ Leptolepides and †Orthogonikleithrus deposited in JME), they are poorly known.

The late ossification of the autopalatine (as in Amia and elopiforms) has been confirmed for certain nonclupeocephalan fossils (see Arratia \& Tischlinger 2010: character 35). Although this character is represented by many question marks in the coding of the fossil forms, the parsimony analysis interprets this character state as present in the fossil clupeocephalans included in the phylogenetic analysis.

Thus, the early ossification of the autopalatine versus its late ossification (in basal forms) is, according to the available information, a unique character of clupeocephalans.

\section{LOWER JAW}

The evolution of the teleostean lower jaw involves some major changes of evolutionary importance that are interpreted as synapormorphies at different levels of Teleostei. For instance, loss of coronoid and surangular bones are synapomorphies of the crown-group Teleostei or Teleocephala (De Pinna 1996). When fossils are included, the loss of coronoid bones stands as a synapomorphy of $†$ Pholidophorus bechei plus more advanced teleosts, and the loss of the surangular is interpreted as a synapomorphy of $†$ Leptolepis coryphaenoides plus more advanced teleosts (Arratia 1999). The lateral position of the posterior opening of the mandibular canal in the angular is a synapomorphy shared by osteoglossomorphs plus clupeocephalans (Arratia 


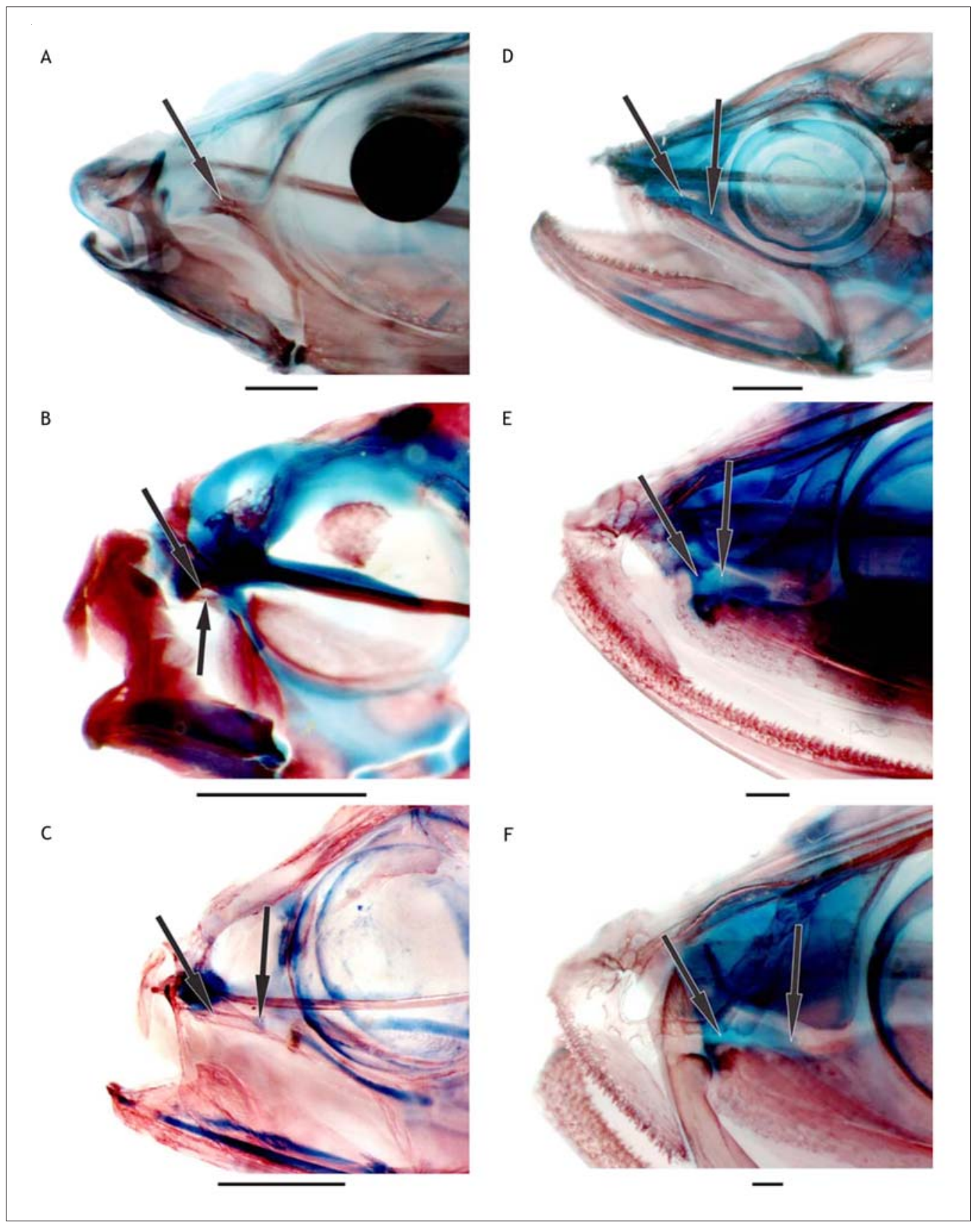

Figure 5. A. Early ossification of the autopalatine in clupeocephalans illustrated in Chanos chanos in lateral view (SIO 80-199; specimen of $44.5 \mathrm{~mm} \mathrm{SL}$ ). B. Cycleptus elongatus in medial view (TU 200816; specimen of $15.8 \mathrm{~mm} \mathrm{SL}$ ). C. Dorosoma cepedianum in lateral view (KU 21801, specimen of $23 \mathrm{~mm} \mathrm{SL}$ ). D. Megalops atlanticus in lateral view (FU 208605, specimen of $44.5 \mathrm{~mm} \mathrm{SL).} \mathrm{E.} \mathrm{Elops} \mathrm{saurus} \mathrm{in}$ lateral view (TCWC 2452.2; specimen of $107 \mathrm{~mm} \mathrm{SL}$ ). F. Elops saurus in lateral view (TCWC 2453.2, specimen of $154 \mathrm{~mm} \mathrm{SL)} \mathrm{illustrating}$ the non-clupeocephalan condition where the autopalatine begins to ossify late in ontogeny. Upper jaw and anterior infraorbitals were removed ( $A, D$, and $E$ ) to facilitate observation of pars autopalatina or autopalatine (indicated by arrows). Chanos and Megalops represent marine fishes that may reach over $\mathbf{1} \mathbf{~ m}$ in length. Scales $\mathbf{1} \mathbf{1} \mathbf{~ m m ~ / ~ A . ~ O s i f i c a c i o ́ n ~ t e m p r a n a ~ d e l ~ h u e s o ~ a u t o p a l a t i n o ~ e n ~ c l u p e o c e ́ f a l o s ~}$ tales como Chanos chanos en vista lateral (SIO 80-199; espécimen de 44,5 mm LS). B. Cycleptus elongatus en vista media (TU 200816; espécimen de 15,8 mm LS). C. Dorosoma cepedianum en vista lateral (KU 21801, espécimen de $23 \mathrm{~mm}$ LS). D. Megalops atlanticus en vista lateral (FU 208605, espécimen de 44,5 mm LS). E. Elops saurus en vista lateral (TCWC 2452.2; espécimen de $107 \mathrm{~mm}$ LS). F. Elops saurus en vista lateral (TCWC 2453.2, espécimen de $154 \mathrm{~mm}$ LS) ilustrando la condición no-clupeocéfala en la cual el autopalatino osifica tardiamente en la ontogenia. La mandíbula superior e infraorbitales anteriores fueron removidos (A, D y E) para facilitar la visibilidad de la pars autopalatina (indicada por flechas). Chanos y Megalops representan peces marinos que pueden alcanzar sobre $1 \mathrm{~m}$ de longitud. Escalas $=1 \mathrm{~mm}$

642 Arratia

Clupeocephala re-visited: Analysis of characters 
1999), whereas the medial or posterior position of the posterior opening is present in more basal teleosts. Cavin (2001) stated that in the elopomorph Albula vulpes the posterior opening of the mandibular canal is placed laterally in the posterior part of the jaw. My observations based on cleared and stained specimens and dry skeletons do not support Cavin's claim, because the opening has a posterior position in the angular. However, if this character was present in Albula, it would not be invalidated as a synapomorphy of osteoglossomorphs plus clupeocephalans, because the position of the medial and/or posterior opening in fossil and recent elopiforms represents the primitive condition; albuliforms are not the most basal elopomorphs. In addition, the taxon sampling used by Cavin (2001) does not permit the variation of the character to be analyzed (e.g., the osteoglossomorphs are absent in his phylogenetic analysis and the elopomorphs are not monophyletic in his analysis: Albula, †Paraelops and clupeocephalans have an unresolved position).

In general, the modern teleostean lower jaw includes four main bones: the dermal dentary anteriorly, and the dermal angular, chondral articular, and retroarticular forming the posterior region of the jaw. In amiiforms, some of the stem-group teleosts, and certain "pholidophoriforms", another dermal bone -the surangular- is the other main element forming the posterior part of the jaw (Fig. 6).

The bones of the posterior part of the lower jaw (the angular, articular, and retroarticular) of teleosts show various patterns of fusion (Nelson 1973a, 1973b). According to Nelson (1973a), the angular fuses either with the articular or with the retroarticular in almost all teleosts, in many teleosts all three bones are fused, and in osteoglossomorphs three patterns are found. Nelson (1973a) also posited that the different fusion patterns have developed at least twice in the evolution of teleosts.

The presence of "angular and articular bones fused, and the retroarticular excluded from the articular surface for the quadrate" is one of the characters supporting the cohort Clupeocephala (Patterson \& Rosen 1977). The character as defined is complex, because on one hand it concerns the relationships (fusion versus non fusion) of the bones forming the posterior region of the lower jaw, and on the other hand it concerns the presence versus absence of the retroarticular bone in the articular facet of the quadrate. Consequently, most authors treat it as two independent characters: 1) "Angular and articular bones are fused". (2) "The retroarticular is excluded from the articular surface for the quadrate".

1) [In adult individuals ...] "Angular and articular bones are fused".

The dermal angular and the chondral articular and retroarticular bones develop from three independent centers of ossification that appear at different times in early ontogeny of extant teleosts. Commonly, the first bone to begin to ossify is the angular at the postero-lateral side of the jaw, followed simultaneously or slightly later by the retroarticular ossification at the ventro-posterior corner of Meckel's cartilage. Later, the articular develops as an ossification of Meckel's cartilage, medial to the angular. During growth, both dermal and chondral ossifications fuse. For examples, see the description of the early ontogeny of

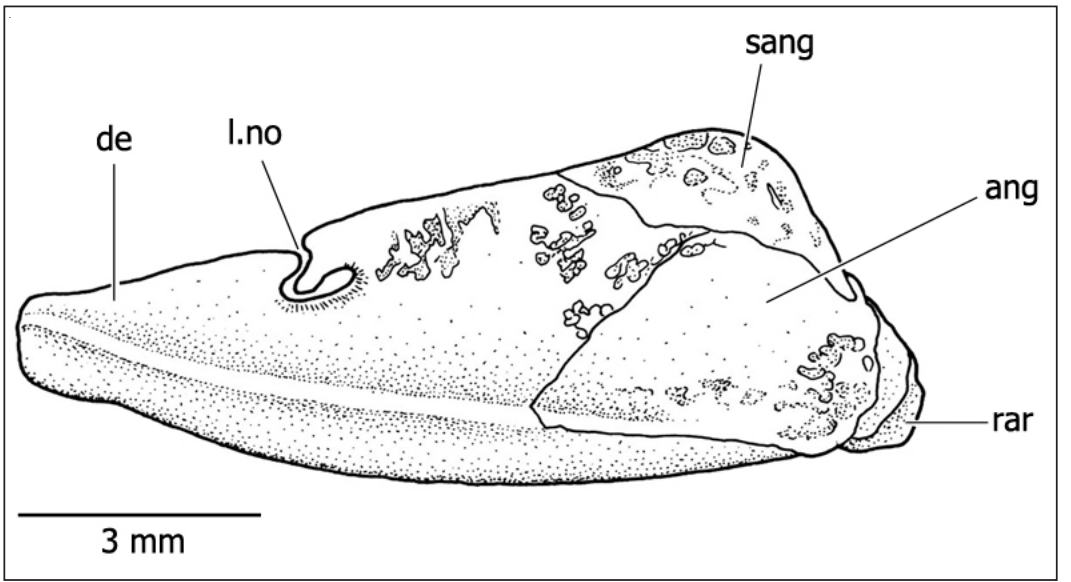

Figure 6. Lower jaw in lateral view of the basal teleost †Pholidophorus latiusculus from the Upper Triassic of northern Italy (MCSNB 4302). Abbreviations: ang, angular; de, dentary; I.no, 'leptolepid' notch; rar, retroarticular; sang, surangular / Mandíbula inferior en vista lateral del teleósteo basal †Pholidophorus latiusculus del Triásico Superior del norte de Italia (MCSNB 4302). Abreviaturas: ang, angular; de, dentario; I.no, escotadura 'leptolepídica'; rar, retroarticular; sang, surangular 
the posterior part of the jaw of Esox by Jollie (1984: 76-77) and of Chanos Arratia \& Bagarinao (2009: 88, figs. 3.4, 3.5). Unfortunately, some authors described, erroneously, the anguloarticular arising from one center of ossification that begins to ossify slightly after the retroarticular (e.g., Langille \& Hall [1987] for Oryzias; Cubbage \& Mabee [1996] for Danio; Engenman et al. [2008] for Catostomus).

The angular and articular bones (Fig. 7A, B) become fused through growth in clupeocephalans. However, these ossifications may be distinct even in large specimens, and it may take some time before a line of suture between the borders of the chondral ossification (articular) and the dermal angular disappears completely (Fig. 8A, B). In contrast, in more basal forms two patterns are observed: (i) Angular and articular bones are independent throughout the life of the individual (e.g., Amia calva, the elopomorph Albula, and the osteoglossomorphs Hiodon and Heterotis. (ii) Angular, articular, and retroarticular are fused. This condition is observed in the Early Jurassic $†$ Pholidophorus bechei and in the "true" basal teleost $\dagger$ Leptolepis coryphaenoides. In the extant elopomorph Megalops, the angular, articular and retroarticular bones become fused during growth, so in large individuals only one ossification (Fig. 9) is observed at the posterior corner of the jaw. There is a fusion between the angular and retroarticular in Elops, and during growth the fusion also includes the articular (Arratia 1987: text-fig. 25A-F, 1997: fig. 85A). This is the condition in $† P h$. bechei, $†$ Leptolepis coryphaenoides, and in $†$ Siemensichthys siemensi (Arratia 2000a: fig. 15E, F). The three bones are also fused in the extant osteoglossomorphs Petrocephalus and Gnathonemus (Hilton 2003), and also in siluriforms among ostarioclupeomorphs (e.g., Diplomystes, Arratia 2003: fig. 1.10).

The presence of a fused angular and articular is accepted as a synapomorphy of the Clupeocephala. However, this is a homoplastic character among teleosts because the fusion between the angular and articular (Fig. 10) is also present in numerous osteoglossomorphs more advanced than Hiodon, such as Chitala, Osteoglossum, Pantodon, Papyrocromus, and Xenostomus (e.g., Taverne 1977, Hilton 2003, pers. obser.). The fusion is also present in fossil basal teleosts such as the †crossognathiforms †Crossognathus saudianus (Taverne 1989: fig. 5), †Rhacolepis buccalis (Forey 1977: fig. 11C), and †Goulmimichthys arambourgi (Cavin 2001). Among members of the †Varasichthyidae, †Varasichthys ariasi has an anguloarticular bone (Arratia 1981: text-fig. 8), but the condition in †Protoclupea and $\dagger$ Domeykos is unclear. Distinct ossifications of both bones are visible, but it remains unknown whether or not they are fused at their confluent medial surfaces. In contrast to †Varasichthys, a retroarticular bone has not been observed in any specimen of $†$ Protoclupea or $†$ Domeykos, nor an articulatory region for it. Therefore, Arratia \& Schultze
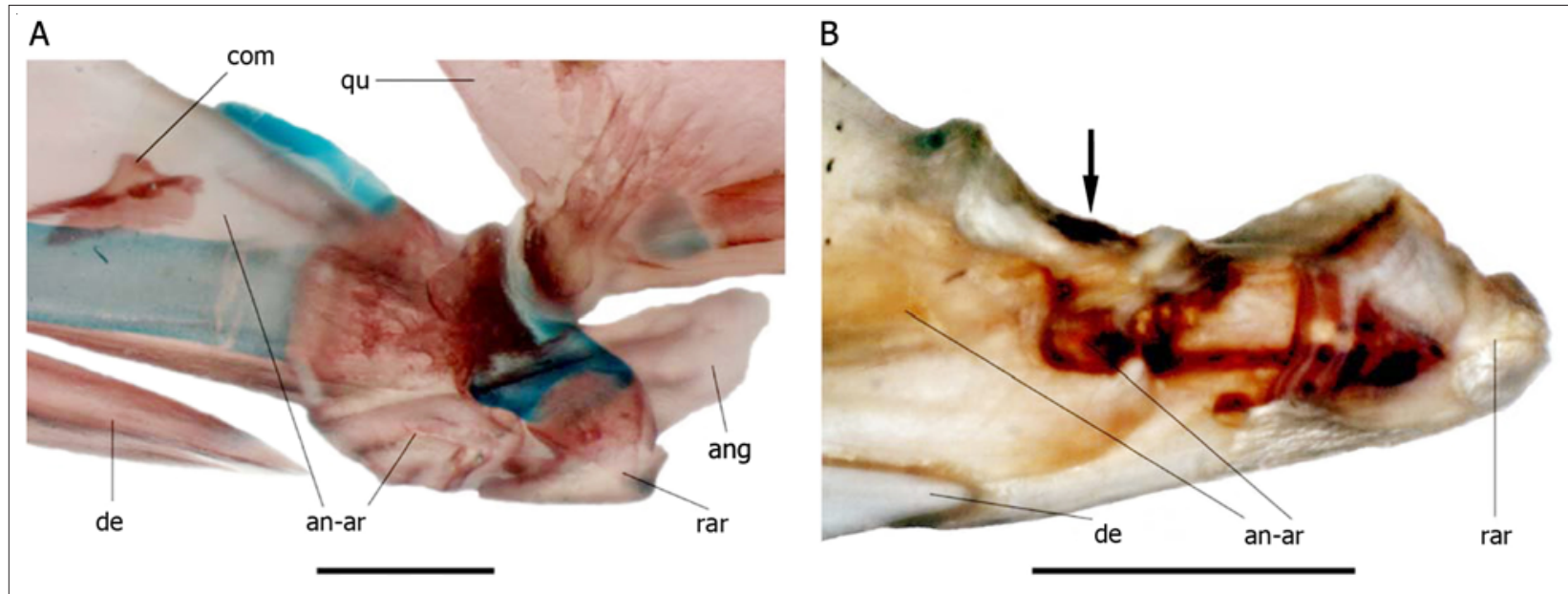

Figure 7. Posterior part of lower jaw in medial view showing the fusion between the dermal angular and the chondral articular. A. Thymallus arcticus (KUMNH 15419; $155 \mathrm{~mm} \mathrm{SL}$ ). Scale = $3 \mathrm{~mm}$. B. Esox lucius (KUMNH 19092; $120 \mathrm{~mm}$ length lower jaw). Scale = $1 \mathrm{~cm}$. Arrow points to the articulatory facet for quadrate. Abbreviations: an-ar, anguloarticular; ang, posterior process of angular; com, coronomeckelian or coronoid bone; de, dentary; qu, quadrate; rar, retroarticular / Parte posterior de la mandíbula inferior en vista interna mostrando la fusión entre los huesos angular (dermal) y articular (condral). A. Thymallus arcticus (KUMNH 15419; $155 \mathrm{~mm}$ de LS). Escala = $3 \mathrm{~mm}$. B. Esox lucius (KUMNH 19092; mandíbula de $120 \mathrm{~mm}$ de longitud). Escala $=1 \mathrm{~cm}$. La flecha apunta a la fosa articular para el cuadrado. Abreviaturas: an-ar, anguloarticular; ang, proceso posterior del angular; com, coronomeckeliano o coronoides; de, dentario; qu, cuadrado; rar, retroarticular

644 Arratia

Clupeocephala re-visited: Analysis of characters 


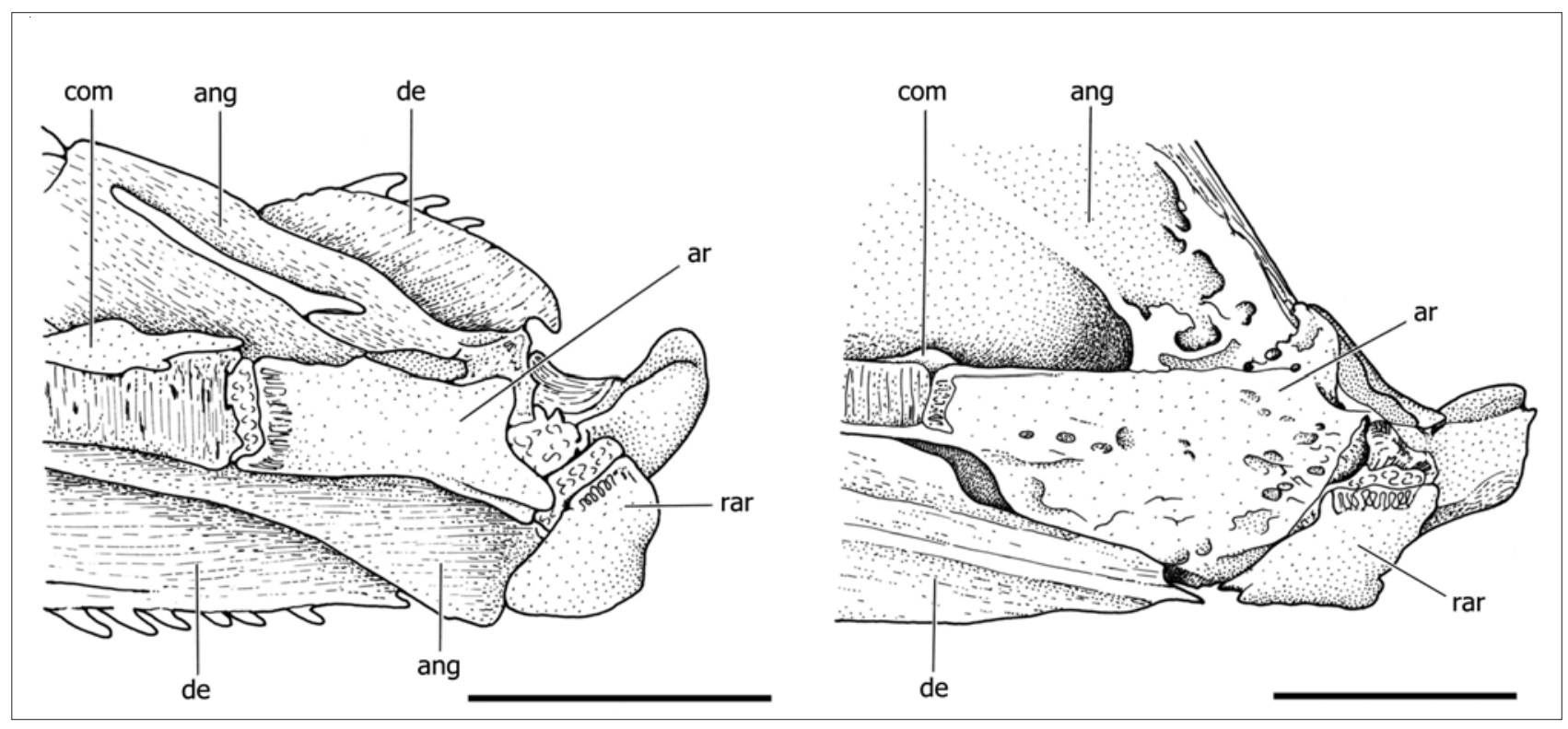

Figure 8. Posterior part of lower jaw in medial view of Denticeps clupeoides (A); Scale $=0.5 \mathrm{~mm}$ and Strangomera benticki (B); Scale = 2 mm (after Arratia 1997). Abbreviations: ang, angular; ar, articular; com, coronomeckelian or coronoid bone; de, dentary; qu, quadrate; rar, retroarticular / Parte posterior de la mandíbula inferior en vista interna de Denticeps clupeoides (A); Escala = 0,5 mm y Strangomera benticki (B); Escala = 2 mm (según Arratia 1997). Abreviaturas: ang, angular; ar, articular; com, coronomeckeliano o coronoides; de, dentario; qu, cuadrado; rar, retroarticular

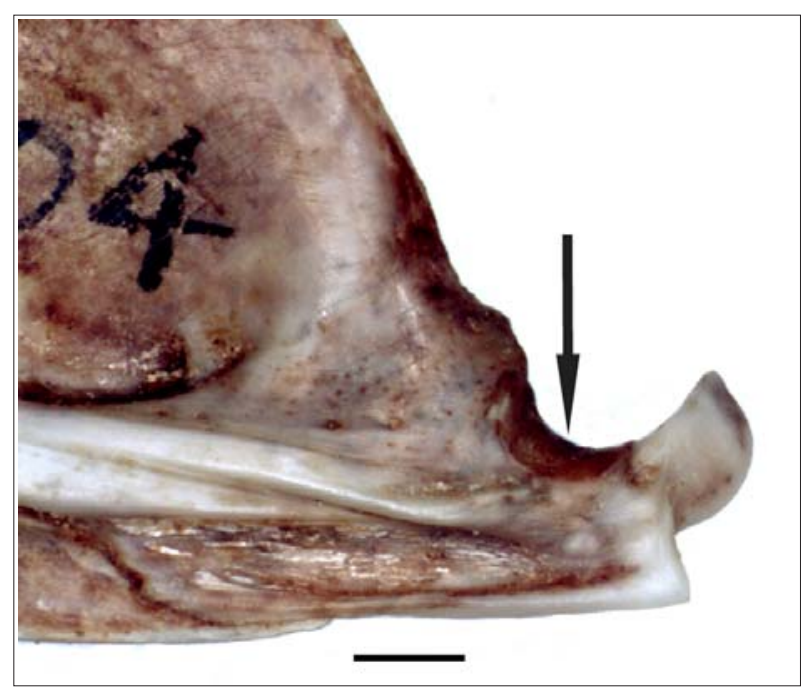

Figure 9. Posterior part of lower jaw of Megalops atlanticus in medial view showing the fusion between the dermal angular and the chondral articular and retroarticular bones (AMNH 211544; 17.8-cm length lower jaw). Arrow points to the articulatory facet for quadrate. Scale $\mathbf{= 1} \mathbf{~ c m}$ / Parte posterior de la mandíbula inferior de Megalops atlanticus, en vista interna, mostrando la fusión entre los huesos angular (dermal), articular y retroarticular (condral) (AMNH 211544; mandíbula de $17,8 \mathrm{~cm}$ de longitud). La flecha apunta a la fosa articular para el cuadrado. Escala $=1 \mathrm{~cm}$
(1985: text-figs. 5, 10, 15B) interpreted the jaws of $\dagger$ Protoclupea and $\dagger$ Domeykos as lacking a retroarticular. However, comparing the jaws of the fossils with those in extant Megalops and the extinct $†$ Leptolepis coryphaenoides, another possibility is that the angular, articular and retroarticular are fused in †Protoclupea and †Domeykos.

According to the present evidence (Fig. 10), and the results of the parsimony analysis, I interpret the presence of a fused anguloarticular in tcrossognathiforms, numerous osteoglossomorphs more advanced than hiodontids, and clupeocephalans as independently acquired in these groups. Cavin (2001), cited in Cavin \& Grigorescu (2005), reached a similar conclusion for the presence of an anguloarticular in the †Crossognathidae.

2) [In adult individuals ...] "Retroarticular excluded from the articular facet for the quadrate".

The main bone forming the facet for articulation with the quadrate is usually the articular; however, the lateral margin may include a small contribution of the angular and, in some fishes, the retroarticular may be part of the facet at the medial side of the jaw. The retroarticular bone is included in the articular facet for the quadrate in teleosts such as elopomorphs and osteoglossomorphs among the crown group Teleostei. In contrast, the bone is restricted to the ventro-posterior corner of the jaw in most 


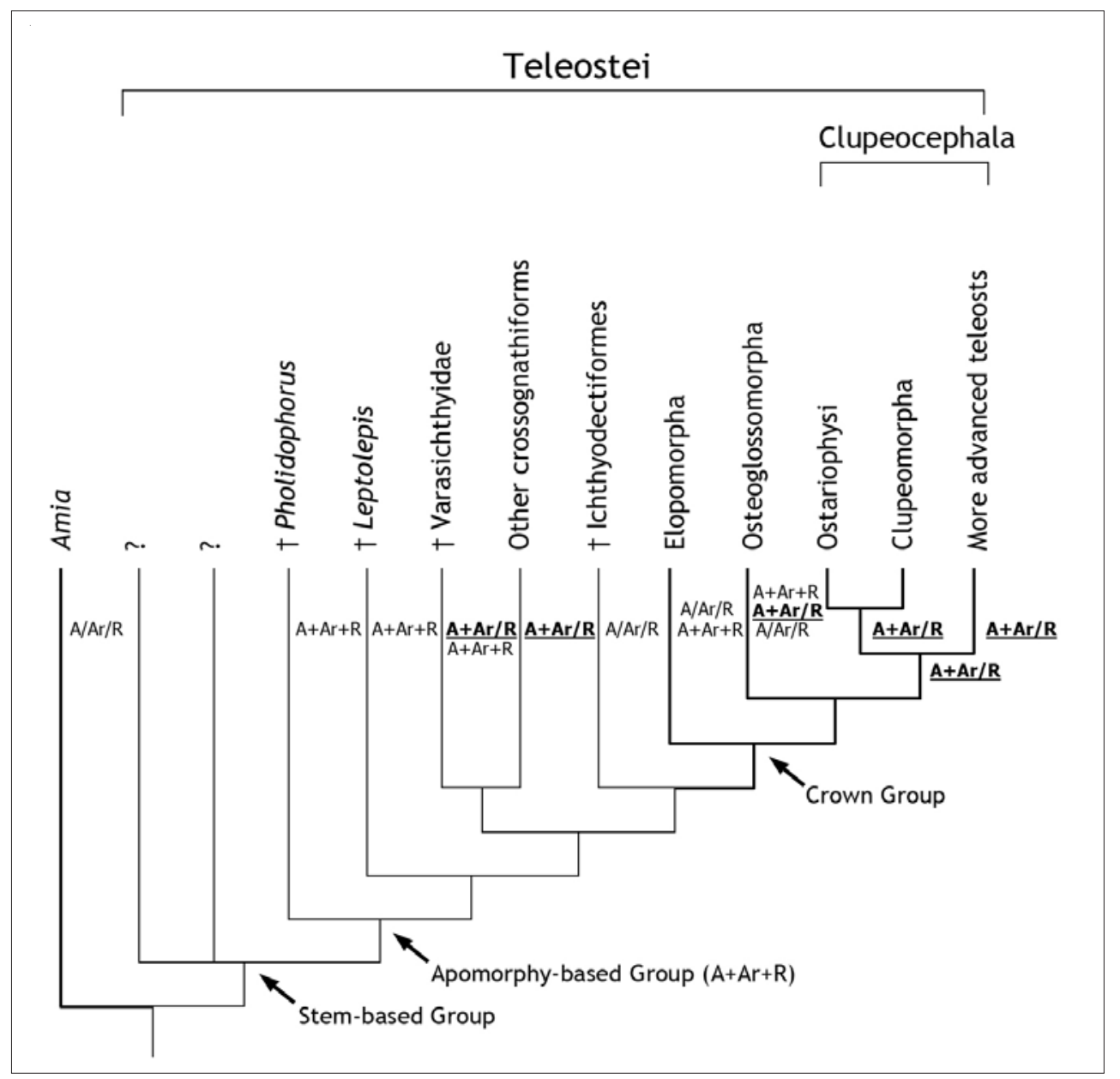

Figure 10. Abbreviated phylogenetic hypothesis of relationships of main lineages of Teleostei (after Arratia 2001) showing the distribution of fusion ( + ) versus non fusion (/) between bones of the posterior part of the lower jaw. The fusion between angular and articular bones $(A+A r / R)$ that it is accepted as a clupeocephalan synapomorphy, is shown in bold and underlined. Abbreviations: A, angular; Ar, articular; R, retroarticular / Hipótesis (abreviada) de relaciones filogenéticas de los linajes principales de Teleostei (según Arratia 2001) mostrando la distribución de la fusión (+) versus no fusión (/) entre huesos de la parte posterior de la mandíbula inferior. La fusión entre angular y articular $(A+A r / R)$, la que es aceptada como una sinapomorfía de clupeocéfalos, se representa en negrita y subrayada. Abreviaturas: A, angular; Ar, articular; R, retroarticular

ostarioclupeomorphs (Fig. 8A, B) and euteleosts (Fig. 7A, $B)$. In the gonorynchiform Chanos, however, the retroarticular that is not included in the articular facet for the quadrate in young and juvenile specimens (Fig. 11A) becomes part of the facet (Fig. 11B) during growth. The retroarticular is tidily sutured with the anguloarticular in specimens over $330 \mathrm{~mm}$ SL.

The presence of a retroarticular excluded from the articular facet for the quadrate is interpreted as a synapomorphy of the Clupeocephala. However, this is a homoplastic character because the retroarticular is included in the articular facet for the quadrate in the clupeocephalan Chanos. Certain osteoglossomorphs such as Osteoglossum and Scleropages (Taverne 1977, Hilton 2003) also have the retroarticular excluded from the facet for the quadrate. In other non-clupeocephalans, such as the †crossognathiforms †Crossognathus saudianus (Taverne 1989: fig. 5), $†$ Rhacolepis buccalis (Forey 1977: fig. 11C), and †Varasichthys ariasi (Arratia 1981: text-fig. 8) the retroarticular is also excluded from the articular facet for the quadrate. Among †ichthyodectiforms, a retroarticular included in the facet for the quadrate is observed in $†$ Allothrissops and †Cladocyclus (Patterson \& Rosen 1977: fig. 8A-C), but the bone is excluded from the articular facet in several genera such as †Ichthyodectes, †Xiphactinus, †Gillicus, †Saurodon (e.g., Nelson 1973a), and $\dagger$ Prosaurodon (Stewart 1999). 
A

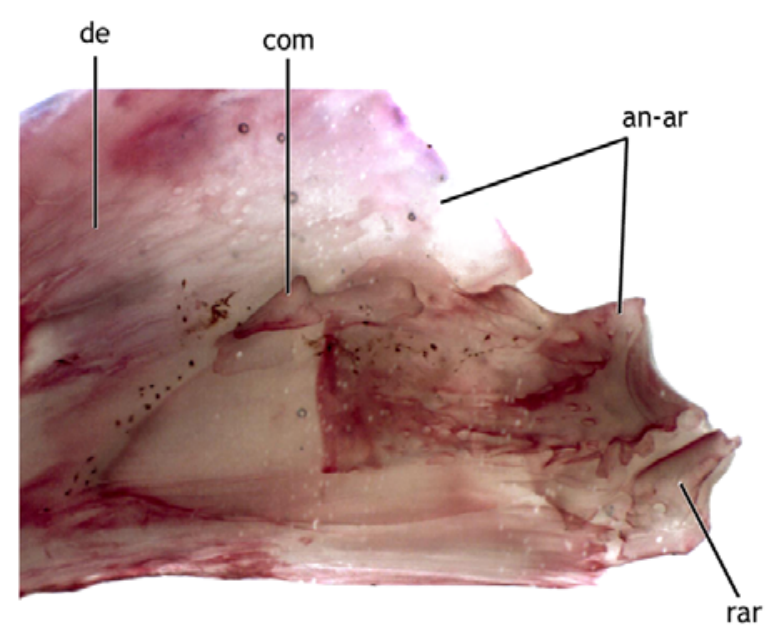

B

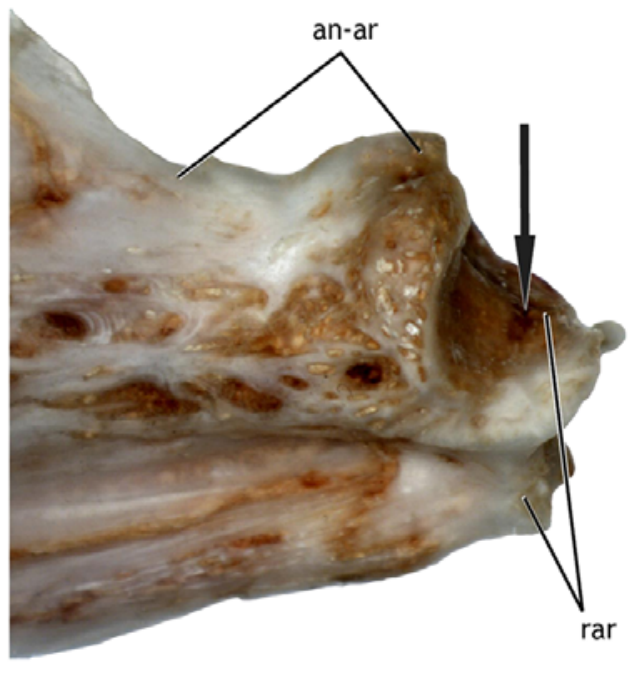

Figure 11. Ontogenetic changes in the posterior part of the lower jaw, shown in medial view, of the gonorynchiform Chanos chanos. A. Retroarticular bone articulates with the anguloarticular (KUMNH 40365; $150 \mathrm{~mm} \mathrm{SL}$ ). Scale $=5 \mathrm{~mm}$. B. The retroarticular becomes part of the articular facet for quadrate (CAS[SU] 35075, $58 \mathrm{~mm}$ length lower jaw); arrow points to the line of suture between the anguloarticular and retroarticular. Scale $=1 \mathrm{~cm}$. Abreviations: an-are, anguloarticular; com, coronomeckelian or coronoid bone; de, dentary; rar, retroarticular / Cambios ontogenéticos en la parte posterior de la mandíbula inferior (en vista interna) del gonorynchiforme Chanos chanos. A. Hueso retroarticular articula con el anguloarticular (KUMNH 40365; $150 \mathrm{~mm} \mathrm{LS}$ ). Escala $=5 \mathrm{~mm}$. B. El retroarticular forma parte de la faceta articular para el cuadrado (CAS[SU] 35075, mandíbula inferior de $58 \mathrm{~mm}$ de longitud); la flecha apunta a la sutura entre el anguloarticular y el retroarticular. Escala $=1 \mathrm{~cm}$. Abreviaturas: an-are, anguloarticular; com, coronomeckeliano o coronoides; de, dentario; rar, retroarticular

According to the current evidence and the results of the parsimony analyses (e.g., Arratia 1999, 2008a, Arratia \& Tischlinger 2010), the presence of the retroarticular excluded from the articular facet for the quadrate is a homoplastic character for teleosts. Nevertheless, because of its distribution, I interpret the presence of this character in †crossognathiforms, †ichthyodectiforms more advanced than $\dagger$ Allothrissops, some osteoglossomorphs more advanced than the hiodontids, and clupeocephalans as a character independently acquired in these groups. The presence of the retroarticular as part of the articulatory facet for quadrate in large specimens of Chanos opens the question about whether this is an autapomorphy of Chanos or if we are missing information about late development of other gonorynchiforms and clupeocephalans that may show a condition similar to that in Chanos.

\section{HYOID ARCH}

"Hyoidean artery piercing ventral hypohyal" (Arratia 1999) versus hyoidean artery piercing one or both dorsal and ventral hypohyals or not piercing the hypohyal(s) (Arratia \& Schultze 1990, De Pinna 1996).
This character stands as a clupeocephalan synapomorphy present among others in clupeomorphs, ostariophysans and protacanthopterygians. To the best of my knowledge, this character is unknown in fossil clupeocephalans and in more advanced euteleosts where the trajectory of blood vessels is unknown or poorly known.

\section{BRANCHIAL ARCHES}

The diversity of the branchial arch elements among teleosts and their phylogenetic importance was first reported by Nelson (1969). During the last 30 years, the branchial arches have been a source of characters for numerous papers, which provide a variety of synapomorphies that identify groups within the clupeocephalans, such as the ostariophysans (Fink \& Fink 1981, 1996), cypriniforms (Siebert 1987), salmoniforms (Rosen 1974), lower euteleosts (Johnson \& Patterson 1996), and higher euteleosts (Rosen 1973).

Most clupeocephalan branchial characters, like those of the caudal skeleton (see below), are problematic because of uncertain homologies. Additionally, the information is available mainly for the extant forms. 
The following characters have been proposed as clupeocephalan synapomorphies:

1) "Tooth plates primitively fused with the first three pharyngobranchials and fifth ceratobranchial" is a complex character proposed as a clupeocephalan synapomorphy by Patterson \& Rosen (1977). Later, the character was modified by Lauder \& Liem (1983) as "Toothplates fused with endoskeletal gill arch elements". In contrast, for Arratia (1999) the character was "Tooth plates not associated with pharyngobranchials 1-3".

This character, independent of the three different versions presented above, faces two problems: (i) erroneous use of anatomical terms, and (ii) the three pharyngobranchials are considered jointly, so that the definition of the character implies that toothplates are consistently associated with all pharyngobranchials 1-3.

Toothplates fused to the first three pharyngobranchials was interpreted as a character of basal clupeocephalans by Patterson \& Rosen (1977). However, my survey of this character in basal and advanced clupeocephalans reveals that the toothplates are never fused with the pharyngobranchial bones, but that when they are present they overlay the bones (e.g., Coilia, Esox, Umbra). Furthermore, most basal euteleosts do not have toothplates associated with pharyngobranchials $1-3$. Consequently, this

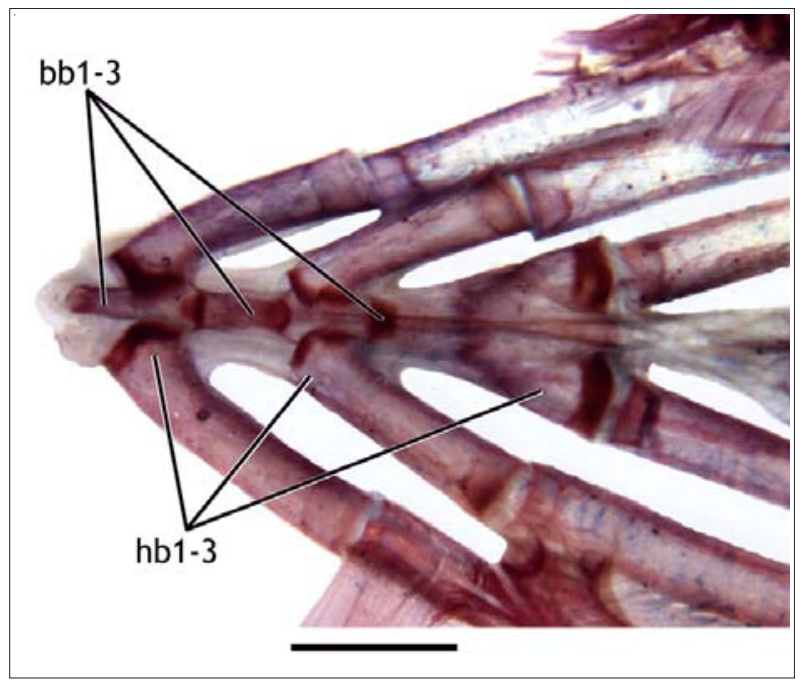

Figure 12. Basibranchial region in dorsal view of the gonorynchiform Chanos chanos (KUMNH 39890; 83 mm SL; Scale $=0.5 \mathrm{~mm}$ ). Note the absence of toothplates. Abbreviations: bb13, basibranchials 1-3; hb1-3, hypobranchials 1-3 / Región basibranquial en vista dorsal del gonorynchiforme Chanos chanos (KUMNH 39890; $83 \mathrm{~mm} \mathrm{LS}$; Escala $=0,5 \mathrm{~mm}$ ). Note la ausencia de placas dentarias. Abreviaturas: bb1-3, basibranquiales 1-3; hb1-3, hipobranquiales 1-3 character -which is based on incorrect observations- does not stand up for the Clupeocephala.

According to Arratia (1999), "absence of tooth plates associated with pharyngobranchials 1-3" is a synapomorphy for basal clupeocephalans. Although this character is based on accurate observations, it faces a problem of homology. The three pharyngobranchials are considered together, but the condition may vary among pharyngobranchials. For instance, no toothplates overly pharyngobranchials 1-3 in most basal clupeomorphs; however, the clupeomorphs Coilia and Jenkinsia and the esocoid Esox have toothplates associated with pharyngobranchials 2-3, but the first pharyngobranchial does not bear a toothplate. Thus, to postulate hypotheses of homology, each pharyngobranchial should be treated independently. Consequently, I separate the character into three different ones with the following results:

i) Toothplate(s) are absent from pharyngobranchial 1 in lower clupeocephalans, so that this character appears to be a synapomorphy supporting the Clupeocephala (however, toothplates are also absent in the basal extant osteoglossomorph Hiodon and in Heterotis).

ii) Toothplates are absent from pharyngobranchial 2 in most basal clupeocephalans, e.g., clupeomorphs (pers. obser.), gonorynchiforms, cypriniforms, siluriforms, gymnotiforms (Fink \& Fink 1996, Arratia pers. obser.), and salmoniforms (pers. obser.). They are also absent in the osteoglossomorph Heterotis. However, they are present in some clupeomorphs (e.g., Coilia and Jenkinsia) and some euteleosts (e.g., Esox) among clupeocephalans.

iii) Toothplates are absent from pharyngobranchial 3 in most basal clupeocephalans, e.g., clupeomorphs (pers. obser.), gonorynchiforms, cypriniforms, siluriforms, gymnotiforms (Fink \& Fink 1996, Arratia pers. obser.), and salmoniforms (pers. obser.). They are also absent in the osteoglossomorph Heterotis. However, they are present in some clupeomorphs (e.g., Coilia, Jenkinsia) and some euteleots (e.g., Esox) among clupeocephalans.

Toothplate(s) fused to ceratobranchial 5 is a condition found in clupeocephalans according to Patterson \& Rosen (1977). However, a toothplate ankylosed or fused to ceratobranchial 5 is a generalized condition among teleosts including elopomorphs, osteoglossomorphs, and clupeocephalans.

2) "Basibranchials 1-3 and basihyal cartilage are not overlain by median tooth plates" (Arratia 1999: 325) versus basibranchials and basihyal cartilages overlain by medial toothplates (Lauder \& Liem 1983 based on Rosen 1982). 
The basibranchials 1-3 and basihyal (Fig. 12) are not overlain by median toothplates in ostarioclupeomorphs among clupeocephalans, but toothplates associated with all these elements (e.g., Esox; Rosen 1974: fig. 1A; pers. obser.) or with one or another are variable present in euteleosts. The parsimony analysis interprets the absence of toothplates from basibranchials 1-3 and basihyal cartilage as a clupeocephalan synapomorphy, but to understand this character properly, I believe that it should be separated into several characters dealing with the presence or absence of toothplates associated with each branchial element, e.g., basihyal, basibranchial 1, basibranchial 2, and basibranchial 3 , so that the homologies involved can be understood. I will deal with a detailed description of these characters elsewhere.

3) "Tooth plate of last pharyngobranchial bone/cartilage formed by growth of one tooth plate" (Arratia 1999).

Pharyngobranchial 4 (or infrapharyngobranchial 4) does not ossify in teleosts, so the fourth pharyngo-branchial element is a cartilage that may bear several toothplates of different sizes and shapes or only one toothplate (see Arratia 1999: figs. 9, 10).

In extant clupeocephalans (including the basal lineages), the toothplate associated with the cartilaginous pharyngobranchial 4 results in the growth of only one toothplate, which is present from early ontogeny on. In some clupeocephalans, e.g., gonorynchiforms, no toothplates are associated with pharyngobranchial 4 or any other branchial element. In contrast, several toothplates are associated with pharyngobranchial 4 in elopiforms (e.g., Elops and Megalops) and basal osteoglossomorphs (e.g., Hiodon).

\section{Caudal Skeleton}

The caudal skeleton, along with the cranium, is one of the most important sources of characters used in phylogenetic studies of teleosts (Arratia 2008b, 2009). The clarity and use of many of the characters from the caudal skeleton suffer from differences in homology assessments between studies regarding the formation of the centra involved in the caudal fin (preural and ural centra) to the origin and homology of elements such as the epurals, uroneurals and hypurals (Schultze \& Arratia 1989, Arratia \& Schultze 1992, Arratia 2008b).

To understand the homologization of the caudal elements, two main conditions are required:

i. Interpretation of the ural region in the polyural fashion, i.e., a one-to-one relationship between a ural centrum and its epaxial and hypaxial elements (Nybelin
1977, Schultze \& Arratia 1989). Only in this way it is possible to understand the relationships between each centrum and its epaxial (e.g., epurals, uroneurals) and hypaxial elements (hypurals) that are usually lost as a result of the upturning of the posteriormost centra and the subsequent displacement of bones.

ii. Study of the origin and development of the preural and ural centra in day-to-day ontogenetic series so that the relationships between the early caudal elements, the loss of some of them, or the fusion of others can be properly understood.

The following caudal skeletal characters have been proposed as clupeocephalan synapomorphies:

"Neural arch over ural centrum 1 reduced or absent, anteriorly directed membranous outgrowths developed from the anterodorsal margin of the first uroneural" (Patterson \& Rosen 1977). Taverne (1989) separated this complex character into two independent ones that he defined as (i) "neural arch of ural centrum 1 reduced, fused with neural arch of preural centrum 1 or lost", and (ii) "enlargement more or less significant of the uroneurals with irregular bony expansions of the ventro-basal side of the first uroneural". Each of these characters however, requires further analysis, as there is variation in the structure of each among clupeocephalan taxa.

\section{1) "Neural arch of ural centrum 1 reduced or lost".}

The ural centrum 1 in the definition by Patterson \& Rosen (1977) corresponds to the first independent centrum placed posterior to preural centrum 1 of the diural terminology (Nybelin 1977). This centrum may correspond to only ural centrum 1 , or only ural centrum 2 or ural centrum $1+2$ of the polyural terminology. The neural arch in question could be the neural arch of different centra. Consequently, as previously defined this character is not homologous among clupeocephalans.

If we assume -based on topological arguments- that the atrophied or absent neural arch that is found posterior to preural centrum 1 correspond to ural centrum 1, then this character is also present outside the clupeocephalans. For instance, it is present in adult Elops (Schultze \& Arratia 1988: figs. 15, 17A, 22) with a small, ossified ural neural arch 1 . It is variably present in adult Hiodon (e.g., Schultze \& Arratia 1988: fig. 7), as well as in †ichthyodectiforms such as †Allothrissops (Patterson \& Rosen 1977: figs. 17, 18A, B) and †Eudiobectes (Patterson \& Rosen 1977: fig. 20). As far the preservation permits, a reduced ural neural arch 1 has been observed in †crossognathiforms such as †Crossognathus and †Domeykos (Arratia 2008a: fig. 4A, B), among others. 

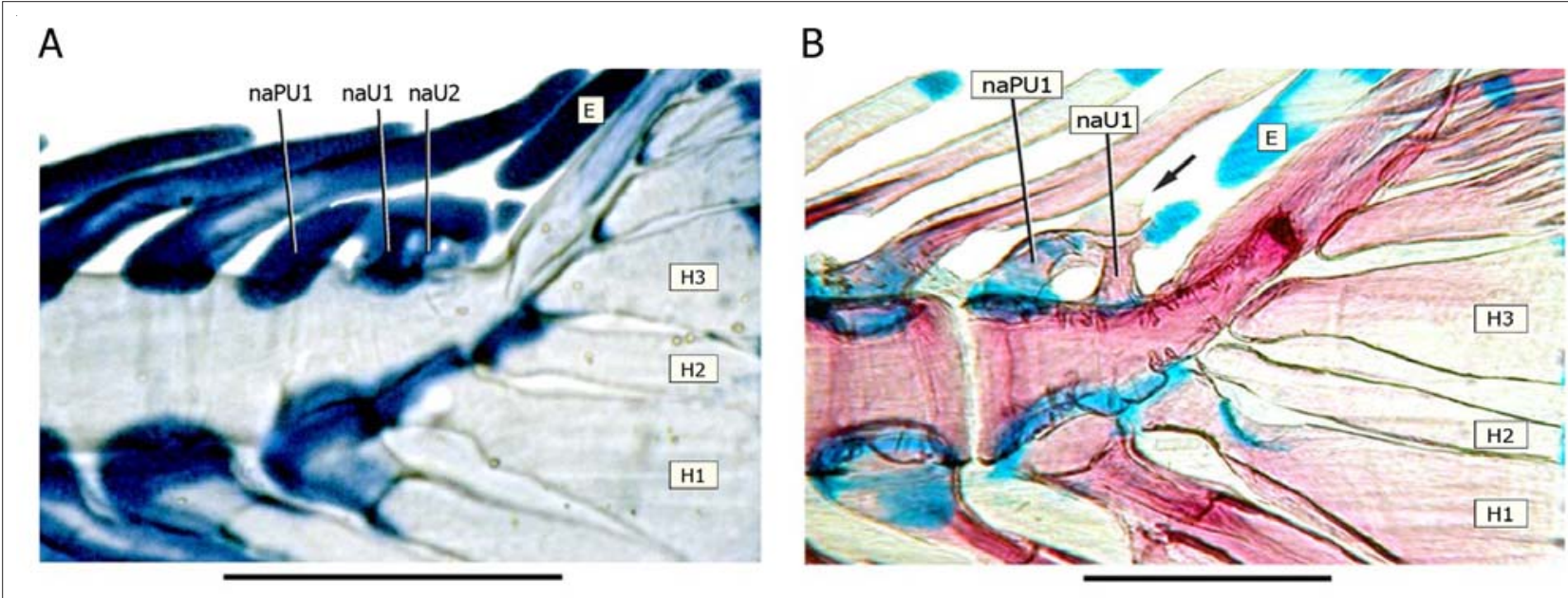

C

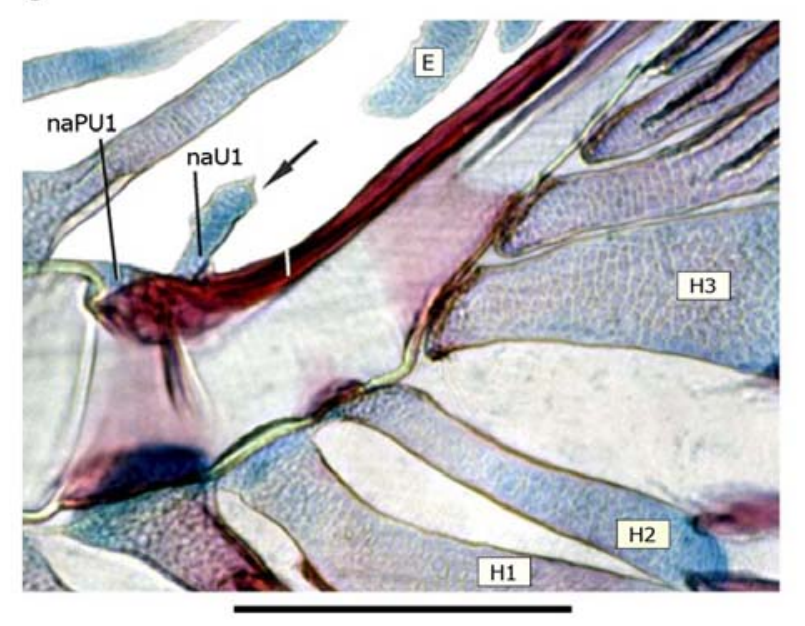

D

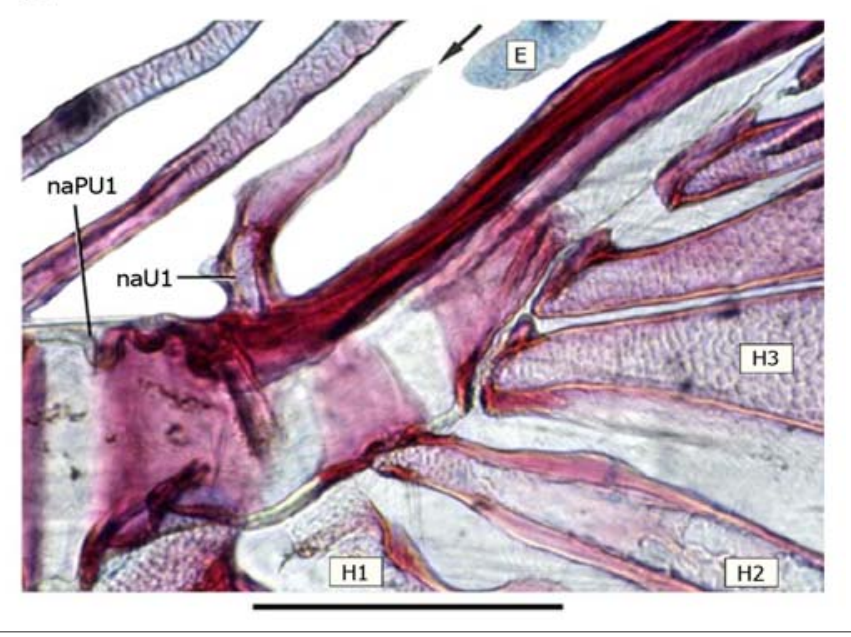

Figure 13. Neural arches and spines of preural centrum 1 and of ural centrum 1 (polyural terminology). A. Chanos chanos (KUMNH 39873; $9.5 \mathrm{~mm} \mathrm{SL}$ ). B. Chanos chanos (KUMNH 39886; $16 \mathrm{~mm} \mathrm{SL}$ ). C. Dorosoma cepedianum (KUMNH 21802; $16.6 \mathrm{~mm} \mathrm{SL).} \mathrm{D.} \mathrm{Dorosoma} \mathrm{cepedianum}$ (KUMNH 21802; $20.8 \mathrm{~mm} \mathrm{SL}$ ). Scale $=0.5 \mathrm{~mm}$. Abbreviations: E, epural; H1-3, hypurals 1-3; naPU1, neural arch of preural centrum 1; naU1-2, neural arch of ural centra 1-2 / Arcos neurales y espinas del centro preural 1 y del centro ural 1 (terminología poliural). A. Chanos chanos (KUMNH 39873; 9,5 mm LS). B. Chanos chanos (KUMNH 39886; $16 \mathrm{~mm} \mathrm{LS).} \mathrm{C.} \mathrm{Dorosoma} \mathrm{cepedianum} \mathrm{(KUMNH} \mathrm{21802;} \mathrm{16,6} \mathrm{mm} \mathrm{LS).} \mathrm{D.}$ Dorosoma cepedianum (KUMNH 21802; 20,8 mm LS). Escala =0,5 mm. Abreviaturas: E, epural; H1-3, hipurales 1-3; naPU1, arco neural del centro preural 1; naU1-2, arco neurales de los centros urales $1-2$

Among extant clupeocephalans, it is assumed that ural neural arch 1 is absent in those fishes possessing a compound centrum and a pleurostyle (= supposedly, modified uroneural 1), such as the ostariophysans. However, the study of early ontogenetic stages shows that the ural neural arches of one or more ural centra become included in the fusion during growth as for example in the gonorynchiform Chanos (Fig. 13A, B) and cypriniforms such as catostomids and cyprinids. Thus, the only arch and spine present in adults is the result of the ontogenetic fusion of the neural arch of preural centrum 1 and that of ural centrum 1, at least. In clupeids the neural arch and spine observed in adults corresponds to the neural arch and spine of ural centrum 1 (Fig. 13C, D). The neural arch of preural centrum 1 (Fig. 13C, D) is atrophied and becomes enclosed by the autocentrum during growth. In other extant clupeocephalans, ural neural arch 1 may be very small or even represented only by a small cartilage (e.g., Thymallus, Arratia \& Schultze: fig. 22A; Fig. 14A herein) or absent (e.g., Oncorhynchus, Arratia \& Schultze: figs. 3, 13, 14; Fujita 1990; Fig. 14B herein). The character is variable among the oldest fossil clupeocephalans. The Late Jurassic $\dagger$ Leptolepides sprattiformis (Fig. 15C) and $\dagger L$. haerteisi have a short neural spine, and consequently a complete ural neural arch 1 (Arratia, 1997: figs. 44, 48), whereas the character is intraspecifically variable in the Late Jurassic 


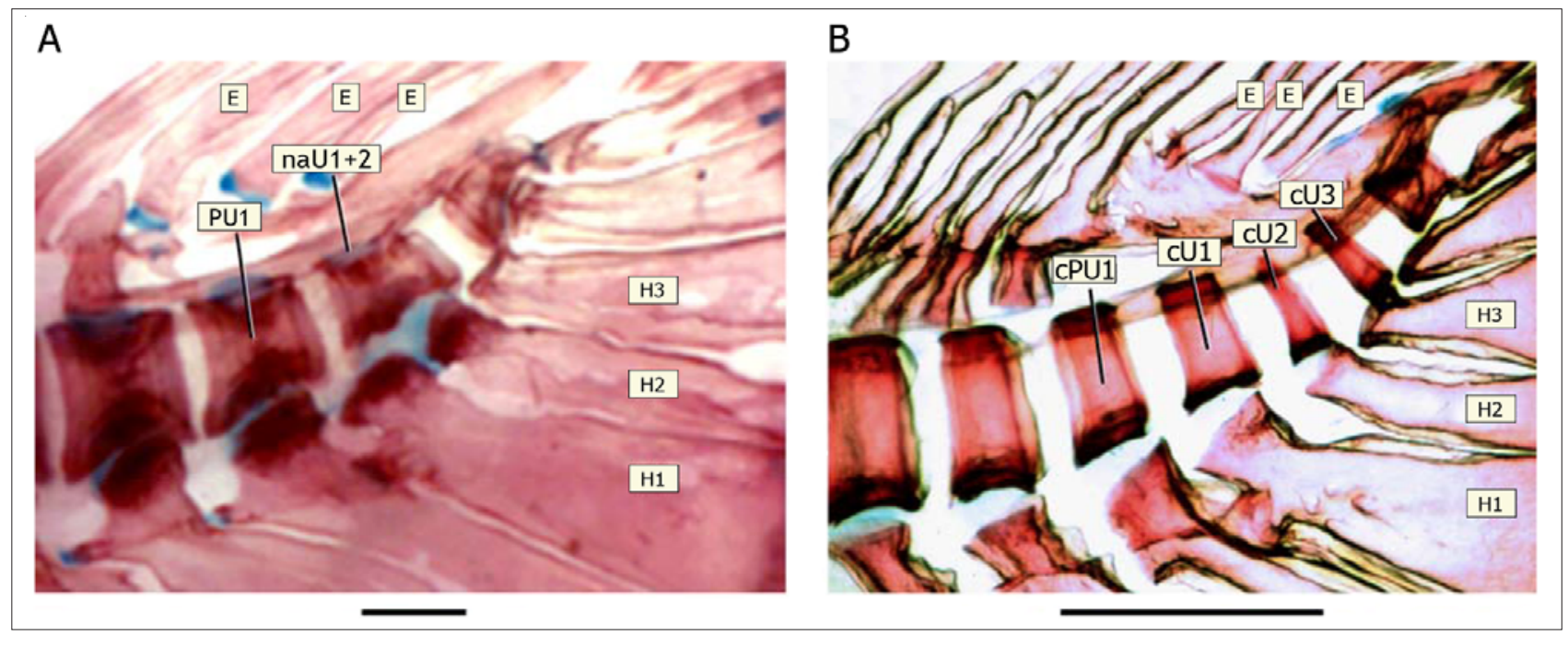

Figure 14. Preural and ural region (polyural terminology) and associated elements. A. Thymallus arcticus (KUMNH 15419; 151 mm SL) illustrating the rudimentary neural arch of ural centrum $1+2$ partially hidden by the stegural. Scale $=3 \mathrm{~mm}$. B. Oncorhynchus mykiss (KU 12463; $28 \mathrm{~mm} \mathrm{SL}$ ). Scale $=0.5 \mathrm{~mm}$. Abbreviations: cPU1, chordacentrum PU1; cU1-3, chordacentra of U1-3; E, epurals; H1-3, hypurals 13; naU1+2, rudimentary neural arch of ural centrum 1+2; PU1, preural centrum 1; U1-3, ural centra 1-3 / Regiones preural y ural (terminologia poliural) y elementos asociados. A. Thymallus arcticus (KUMNH 15419; $151 \mathrm{~mm}$ LS) mostrando el arco neural rudimentario del centro ural $1+2$ parcialmente cubierto por el estegural. Escala $=3 \mathrm{~mm}$. B. Oncorhynchus mykiss (KU 12463; $28 \mathrm{~mm}$ LS). Escala $=0,5 \mathrm{~mm}$. Abreviaturas: cPU1, cordacentro PU1; cU1-3, cordacentros de los U1-3; E, epurales; H1-3, hipurales 1-3; naU1+2, arco neural rudimentario del centro ural 1+2; PU1, centro preural 1; U1-3, centros urales 1-3

†Orthogoniklethrus leichi and †O. hoelli, with a short ural neural spine 1 (Arratia 1997: fig. 61A) in a few specimens, and a lack of spine and presence of an atrophic ural neural arch 1 in most specimens (Arratia 1997: figs. 53, 60, 61B, C).

Consequently, as new ontogenetic information demonstrates, the neural arch and spine present in extant ostarioclupeomorphs are not the neural arch and spine of preural centrum 1, but may be the result of the fusion of the neural arches of preural centrum 1 and ural centrum 1 or the arch of ural centrum 1 alone. My survey of basal euteleosts to date shows that a reduced or absent neural arch of ural centrum 1 is a feature consistently present in euteleosts.

2) "Neural spine of ural centra 1 and 2 (polyural terminology)" or "ural centrum 1 absent" versus presence of neural spine. This character was proposed by Arratia (1999) to test the position of †Leptolepides and †Orthogonikleithrus (bearing a neural spine on ural centrum 1; Fig. 15C) as basal clupeocephalans.

However, as new information on early development shows a neural spine of ural centrum 1 is present in extant clupeids and engraulids (Fig. 13C, D) and the spine found in ostariophysans may correspond to the ontogenetic fusion of the neural spines of preural centrum 1 and ural centrum 1 (Fig. 13A, B). To the best of my knowledge, the absence of the ural neural spine 1 (Figs. 15D, 14A, B) occurs consistently in extant euteleosts among clupeocephalans (see illustrations in Fujita 1990) because their arch is reduced or absent (see above). According to the new information this character could be a euteleostean synapomorphy instead of a clupeocephalan synapo-morphy.

3) "Anteriorly directed membranous outgrowths developed from the anterodorsal margin of the first uroneural" (Patterson \& Rosen 1977) or "enlargement more or less significant of the uroneurals with irregular bony expansions of the ventro-basal side of the first uroneural" (Taverne 1989).

This character refers to the first uroneural based on the assumption that the first uroneural in all teleosts develops as a modification of the same ural neural arch. If we assume that the first uroneural in basal clupeocephalans is homologous among groups, then we conclude that the anteriorly directed membranous outgrowths are missing in many extant engrauloids (see for instance Fujita 1990: figs. 17, 18, 26, 27, 28), and in most ostariophysans (see for instance Fujita 1990: figs. 32-51). Membranous outgrows developed from the anterodorsal margin of the so-called first uroneral are present in basal euteleosts such as the Late Jurassic genera $\uparrow$ Leptolepides and $\uparrow$ Orthogonikleithrus and the Cretaceous genera $†$ Erichalcis, $†$ Manchurichthys and †Humbertia (see Arratia \& Schultze 1992: fig. 27A- 


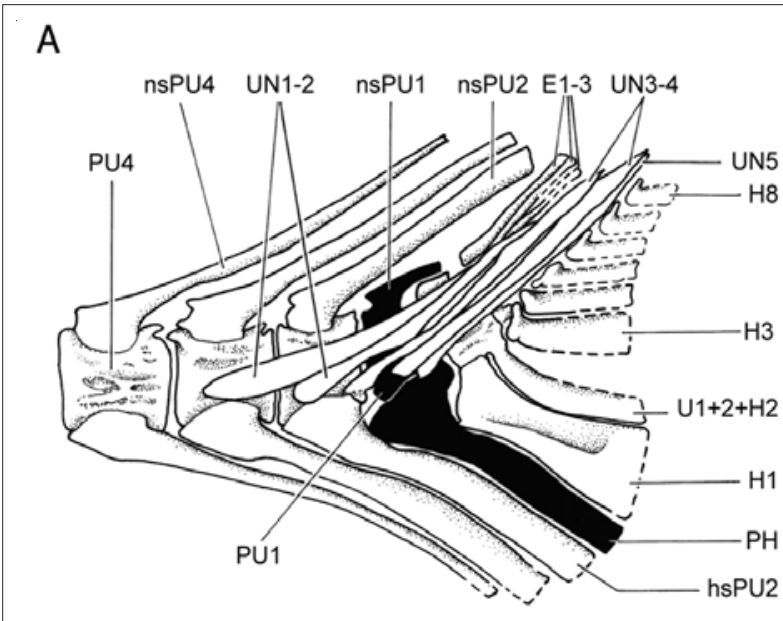

C

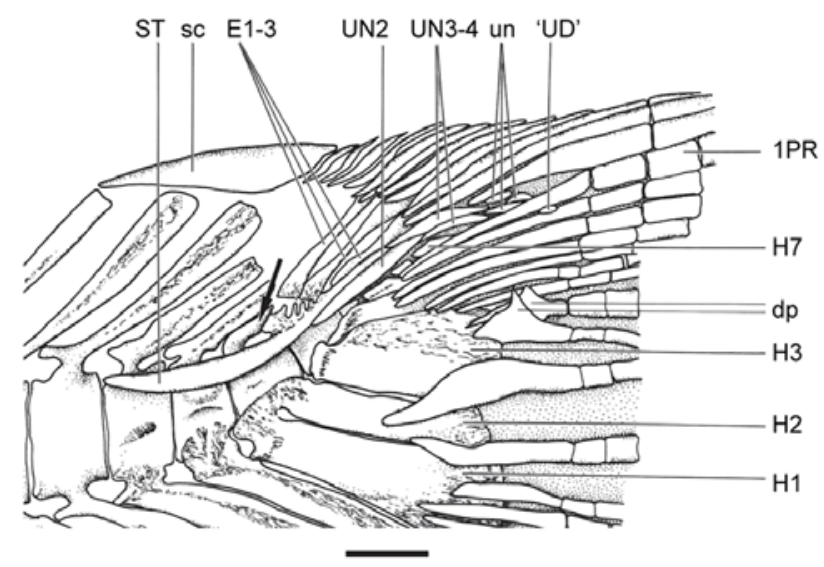

B

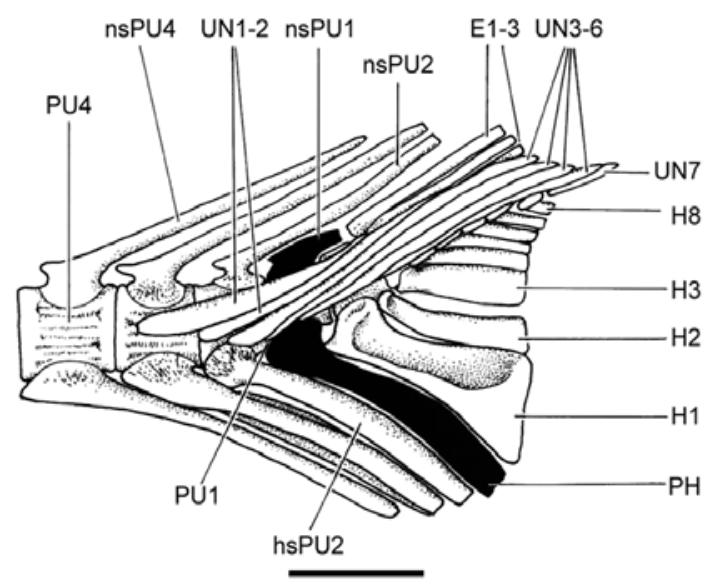

D

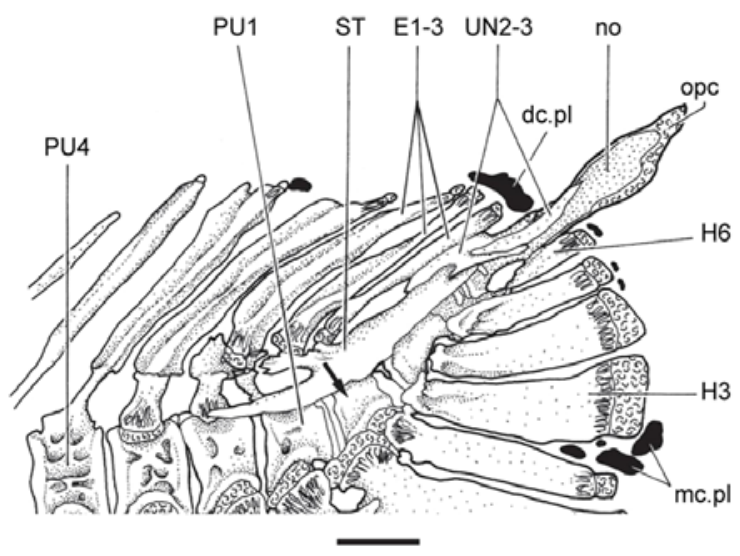

Figure 15. Caudal skeletons illustrating the primitive alignment of the uroneural series (A, B) versus the clupeocephalan alignment (C, D). A. †Allothrissops sp. from the Kimmeridgian of Schamhaupten, Germany. B, †Allothrissops mesogaster from the Tithonian of Kelheim, Germany (modified from Arratia 2000c). Scale $=5 \mathrm{~mm}$. C. †Leptolepides sprattiformis (SMNS 55928). Arrow points to the neural spine on ural centrum 1+2. Scale $=0.5 \mathrm{~mm}$. D. Thymallus arcticus (KUMNH 15419; $151 \mathrm{~mm} \mathrm{SL;} \mathrm{Scale}=1 \mathrm{~mm}$ ). The arrow points to the ural centrum 1+2. Abbreviations: dc.pl, cartilaginous distal plate; dp, dorsal processes of principal rays; E1-3, epurals 1-3; H1-8, hypurals 1-8; hsPU2, haemal spine of PU2; mc.pl, cartilaginous middle distal plate; no, notochord; nsPU1-4, neural spine of PU1-4; PH, parhypural; PU1-4, preural centra 1-4; U1+2+H2, ural centrum 1+2 plus hypural 2; 'UD', 'urodermal'; un, uroneural-like elements; UN1-7, uroneurals 1-7; ST, stegural; 1PR, first principal ray / Esqueletos caudales mostrando la disposición primitiva de los uroneurales ( $\mathrm{A}$, B) versus la disposición en los clupeocéfalos (C, D). A. †Allothrissops sp. del Kimmeridgiano de Schamhaupten, Alemania. B. †Allothrissops mesogaster del Titoniano de Kelheim, Alemania (modificado de Arratia 2000c). Escala $=5 \mathrm{~mm}$. C. †Leptolepides sprattiformis (SMNS 55928). La flecha apunta a la espina neural del centro ural 1+2. Escala $=0,5 \mathrm{~mm}$. D. Thymallus arcticus (KUMNH 15419; $151 \mathrm{~mm} \mathrm{LS}$; Escala $=1 \mathrm{~mm}$ ). La flecha apunta al centro ural $1+2$. Abreviaturas: dc. pl, placa cartilaginosa distal; dp, procesos dorsales de los rayos principales; E1-3, epurales 1-3; H1-8, hipurales 1-8; hsPU2, espina hemal del PU2; mc. pl, placa cartilaginosa distal media; no, notocorda; nsPU1-4, espinas neurales de los PU1-4; PH, parahipural; PU1-4, centros preurales 1-4; U1+2+H2, centro ural 1+2 + hipural 2; 'UD', 'urodermal'; un, elementos tipo uroneural; UN1-7, uroneurales 1-7; ST, estegural; $1 \mathrm{PR}$, primer rayo principal 
D). In salmonids, where the origin and development of the so-called first uroneural (= stegural) has been investigated (Arratia \& Schultze 1992), the first uroneural or anteriormost uroneural develops as a modification of the ural neural arch of ural centrum 4 of the polyural terminology. Thus, the expanded membranous ourgrowth found in salmonids does not belong to uroneural 1, but to uroneural 4 of the polyural terminology.

Studies based on early ongenetic stages are mandatory if we want to understand whether the so-called uroneural 1 develops from the same ural neural arch among different teleostean subgroups, in other words, if the uroneural 1 is homologous among teleosts (Schultze \& Arratia 1989). As the stegural, the pleurostyle of ostarioclupeomorphs is commonly interpreted as a modified uroneural 1 ; however, it is unknown if the pleurostyle develops as a modification of the neural arch of ural centrum 1 (polyural terminology) or if develops from the same ural neural arch (other than ural neural arch 1) in all ostariophysans and clupeomorphs.

To the best of my knowledge, and independently of the ambiguous homology, the character discussed in this section has not been considered by most authors dealing with clupeocephalan or teleostean phylogenetic analyses.

In the following section, I analize other two potential characters mentioned in the literature: "All uroneurals are not inclined toward the horizontal", but are aligned in different angles (Arratia 1999, 2008a), and "six hypurals present" (Patterson \& Rosen 1977). This section ends with comments on a problematic character ("Stegural present").

4) "All uroneurals are not inclined toward the horizontal", but are aligned in different angles, in contrast to the situation present in basal teleosts (Arratia 1999, 2008a).

In basal teleosts the uroneurals are aligned at similar angles (Fig. 15A, B). This condition can be found in †Leptolepis coryphaenoides (e.g., Arratia 1991: fig. 7), †ichthyodectiforms (e.g., Patterson \& Rosen 1977: figs. 14, 17-21, Arratia 1997: figs. 24-25), extant teleosts such as the basal elopiforms Elops and Megalops (e.g., Schultze \& Arratia 1988: figs. 7, 17A), and the basal osteoglossomorph Hiodon (e.g., Schultze \& Arratia 1988: figs. 7, 11A-D, Hilton 2002: figs. 74, 76A-F). In contrast, in basal clupeocephalans, the last uroneurals (Fig. 15C, D) are aligned at a different angle with respect to the anterior series of uroneurals. The alignment of the uroneurals at different angles is a character shared by fossil (e.g., †Leptolepides, Patterson \& Rosen 1977: fig. 50, Arratia 1997: figs. 44, 48; †Orthogonikleithrus, Arratia 1997: figs. 61A, B) and extant clupeocephalans (e.g., Fujita 1990: figs. 16, 17, 20, $23,25,29,35,38,44,62$, and many others). However, it is unclear whether the last uroneurals are homologous in different teleostean subgroups (see above and Arratia 1996b: fig. 6, 1997).

5) "Six hypurals present" (Patterson \& Rosen 1977). The correct definition of the character should be: "Six or fewer hypurals present" (see explanation below).

Six or fewer ossified hypurals (Fig. 14B) are present in extant clupeocephalans (e.g., see figs. 15-49, 54-73, and 96-111 in Fujita 1990), in contrast to seven or more ossified hypurals in more basal forms such as $\dagger$ Leptolepis coryphaenoides, †Tharsis, †Varasichthyidae (among the †crossognathiforms), †ichthyodectiforms, Elops, Megalops, $\dagger$ Lycoptera, and Hiodon. However, Late Jurassic basal euteleosts such as †Leptolepides and †Orthogonikleithrus retain the primitive condition of seven hypurals (Arratia 1997: figs. 44, 48, 53, 61; Fig. 15C herein), but Cretaceous euteleosts such as †Manchuricthys, †Erichalcis and †Humbertia, among others, present six or five hypurals (Arratia \& Schultze 1992: fig. 27B-D). Occasionally, additional cartilaginous hypurals may be found in early ontogeny of extant clupeocephalans.

The presence of six or fewer hypurals is not unique to clupeocephalans among teleosts because the character is also present in non-clupeocephalans, such as some †pachyrhyzodontoids (among †crossognathiforms), the extant elopomorphs Albula and Pterothrissus and more advanced forms such as notacanthids and anguilliforms (Schultze \& Arratia 1988: figs. 25B, 26, Fujita 1990: figs. 8, 9-14), and all osteoglossomorphs above hiodontids (Hilton 2003: character 71).

According to the evidence presented here and the results of recent parsimony analyses (e.g., Arratia 1999, 2008a), the presence of six or fewer hypurals is interpreted as a homoplastic character for teleosts. Nevertheless, because of its taxonomic distribution, I interpret the presence of this character in some †crossognathiforms, some elopomorphs more advanced than the basal elopiforms Elops and Megalops, some osteoglossomorphs more advanced than the hiodontids, and clupeocephalans as a character independently acquired in these groups.

\section{6) "Stegural present" (Arratia 2008a).}

The presence of a stegural has been suggested as a euteleostean character by Patterson \& Rosen (1977) and Arratia (1999). However, in a recent phylogenetic analysis of basal teleosts (Arratia 2008a) with the †crossognathiforms 
included, the parsimony analysis places the groups with a stegural at the base of clupeocephalans (including fishes that previously were interpreted as "salmoniforms"). The stegural is lost in ostarioclupeomorphs, but present in basal clupeocephalans †Erichalcis, †Humbertia, †Leptolepides, and †Orthogonikleithrus (but see Arratia \& Tischlinger 2010 where $†$ Erichalcis, $†$ Humbertia, $†$ Leptolepides and †Orthogonikleithrus are recovered as euteleosts).

As mentioned above, it is unclear whether the so-called stegural is a modification of the same uroneural in clupeocephalans, making the homology of this structure unlikely. The origin and development of the stegural has only been described and illustrated for salmonids (see Arratia \& Schultze 1991). Currently, I interpret this character as doubtful, either for clupeocephalans or euteleosts, and the only way to solve the problem-in my opinion-is to study day-to-day ontogenetic series of fishes interpreted as possessing a stegural, so that the origin of the element can be known.

\section{DisCUSSION AND CONCLUSIONS}

The Osteoglossocephala, including the Clupeocephala is without doubt the largest formal clade among Teleostei. A great morphological diversification and consequently numerous evolutionary transformations through time and among and within subgroups is expected for such a large group. These properties, in addition to the high levels of homoplasies of numerous characters, complicate the study of this group and its phylogenetic relationships.

One interesting result of this study and re-evaluation of clupeocephalan characters is that some of the synapomorphies that were previously proposed to be uniquely derived for clupeocephalans are interpreted as homoplastic when certain fossils are included in the phylogenetic analysis (e.g., Arratia 2008a, Arratia \& Tischlinger 2010). This confirms again the importance of fossils in the understanding of the evolutionary history of certain characters, and obviously, of the evolutionary history of the group under study (see Arratia 2001, 2004 concerning the importance of fossils). Another interesting result is that this study demonstrates the importance of ontogenetic investigations for systematic and phylogenetic interpretations, including from early to late stages of development. It shows, once more, that the understanding of the different elements of the caudal skeleton, their transformations, their variations, and consequently the homologies involved, requires careful observations on the origin and formation of these structures from early stages of growth, which may vary among groups. Developmental investigations are not only a necessity for understanding the caudal skeleton, but as it is shown here, these investigations are important for other characters as well. Other interesting result is the discovery that several clupeocephalan synapomorphies are also present in recent osteoglossomorphs more advanced than the primitive hiodontids, a fact that also changes the interpretation of some characters as homoplasies.

In sum, re-evaluation of the characters demonstrate the existence of several problems: (i) several of these characters are not uniquely derived, but are homoplastic characters also found in some tcrossognathiforms among basal teleosts and in osteoglossomorphs above the level of hiodontids (e.g., fused anguloarticular, retroarticular excluded from the articular surface for quadrate); (ii) others are absent in most basal forms (e.g., an atrophied or absent ural neural arch 1); (iii) others are variably present among basal clupeocephalans (e.g., toothplates on pharyngobranchials 2 and 3); and (iv) others seem to be erroneous (e.g., toothplates primitively fused with the first three pharyngobranchials and fifth ceratobranchial). Some characters as defined previously represent ambiguous homologies (e.g., basibranchials 1-3 and basihyal cartilage are not overlain by medial toothplates; neural arch of ural centrum 1 [diural terminology] reduced or lost; anteriorly directed membranous outgrowths developed from the anterodorsal margin of the first uroneural; stegural present).

According to the present evidence the monophyly of the Clupeocephala is supported by numerous, unambiguous characters. Several of them, listed below, are apparently uniquely derived:

1. Autopalatine bone ossifies early in ontogeny.

2. Hyoidean artery pierces ventral hypohyal.

3. Toothplate of cartilaginous fourth pharyngobranchial element forms by growth of only one toothplate and not by fusion of several plates.

According to the results presented here, the following characters are homoplastic because they are also found in other groups outside the Clupeocephala, such as in some †crossognathiforms and/or in advanced osteoglossomorphs or because the basal gonorynchiform Chanos presents a different condition in adult stage. Because of their distribution among teleosts, these characters are interpreted here as independently acquired in these lineages and, consequently, they may be considered as clupeocephalan synapomorphies: 
4. Uroneurals are aligned at different angles, instead of all being inclined toward the horizontal.

5. Angular and articular bones are fused.

6. Retroarticular bone is excluded from the articular facet for the quadrate.

7. Toothplates on pharyngobranchial 1 are absent.

8. Toothplates on pharyngobranchial 2 are absent.

9. Toothplates on pharyngobranchial 3 are absent.

10. Six or fewer hypurals are present.

One character that previously was interpreted as a clupeocephalan synapomorphy is proposed here as a euteleostean synapomorphy:

Neural arch of ural centrum 1 (of the polyural terminology) is reduced or lost.

The presence of a neural spine on ural centrum 1 may be a synapomorphy of some clupeomorph subgroups.

Finally, the information provided in this study changes previous interpretations of certain characters and reveals the need for further morphological, developmental, and phylogenetic studies based on more elopomorph, osteoglossomorph, and clupeocephalan taxa, including both basal and more advanced species. In this way, the meaning and distribution of the homoplastic characters may be better understood, permitting a better interpretation of these characters. A larger study will also facilitate testing which characters represent unique novelties at certain levels of Teleostei.

\section{ACKNOWLEDGMENTS}

Dedicated to the memory of my friend and colleague, Professor Ismael Kong Urbina.

I thank G. Pequeño (Universidad Austral de Chile) for providing the information concerning this special volumen dedicated to the memory of Ismael Kong Urbina. Thanks are due to the following individuals and institutions for permission to study material under their care: A Bentley (KUMNH), H Bjerring (SMNH), R Böttcher (SMNS), D Butt (UCLA), CH von Daniels (BGHan), W Eschmeyer and D Catania (CAS), WL Fink and D Nelson (UMMZ), L Grande, M Westneat and MA Rogers (FMNH), H Jahnke (GOE), late K Liem and K Hartel (MCZ), M Koelb-Ebert and G Viohl (JME), M Louette and †G Teugels (MRAC), D Markle (OS), A Paganoni (MCSNB), J McEacharan and M Retzer (TCWC), L Parenti (USNM), N Rios (TU), T Robins (UF), R Rosenblatt (SIO), W Saul (ANSP), A
Simons and V Hirt (JFBM), M Stiassny (AMNH), P Wellnhofer and O Rauhut (BSPG). To the late M Coburn (John Carroll University), to the late I Kong U (Antofagasta, Chile), and Y-Y Chen (Academia Sinica, Hunan, China), Paula Mabee (University of South Dakota), K Matsuura (National History Museum, Tokyo), and S Poss (Gulf Coast Research Laboratory), for the gift of some important specimens included in this study. To H-P Schultze and EO Wiley (University of Kansas) for comments and discussion on phylogenetic interpretations and methodologies, Sarah Rages for improving the style of the manuscript, and MP Davis and FR Abe (University of Kansas) for helping with the preparation of the illustrations for electronic submission. Special thanks to GD Johnson (US National Museum) and E Hilton (Virginia Institute of Marine Sciences) for reviewing the manuscript. This is a contribution of grant NSF EF 0431326, Collaborative Research: Systematics of Cypriniformes, Earth's Most Diverse Clade of Freshwater Fishes.

\section{LITERATURE CITED}

Arratia G. 1981. Varasichthys ariasi n. gen. et sp. from the Upper Jurassic of Chile (Pisces, Teleostei, Varasichthyidae). Palaeontographica A 175: 107-139.

Arratia G. 1987. Anaethalion and similar teleosts (Actinopterygii, Pisces) from the Late Jurassic (Tithonian) of southern Germany and their relationships. Palaeontographica A 200: 1-44.

Arratia G. 1991. The caudal skeleton of Jurassic teleosts; a phylogenetic analysis. In: Chang M-M, Y-H Liu \& G-R Zhang (eds). Early vertebrates and related problems in evolutionary biology, pp. 249-340. Science Press, Beijing.

Arratia G. 1992. Development and variation of the suspensorium of primitive catfishes (Teleostei: Ostariophysi) and their phylogenetic relationships. Bonner Zoologische Monographien 32: 1-149.

Arratia G. 1996a. Basal teleosts and teleostean phylogeny. PhD Dissertation, University of Uppsala, Uppsala, 318 pp.

Arratia G. 1996b. The Jurassic and the life history of teleosts. In: Arratia G \& G Viohl (eds). Mesozoic fishes -Systematics and paleoecology, pp. 219-242. Verlag Dr. F. Pfeil, München.

Arratia G. 1997. Basal teleosts and teleostean phylogeny. Palaeo Ichthyologica 7: 1-168.

Arratia G. 1998. Basal teleosts and teleostean phylogeny: response to C. Patterson. Copeia 1998(4): 1109-1113.

Arratia G. 1999. The monophyly of Teleostei and stem-group teleosts. Consensus and disagreements. In: Arratia G \& H-P Schultze (eds). Mesozoic fishes 2 -Systematics and fossil record, pp. 265-334. Verlag Dr. F. Pfeil, München.

Arratia G. 2000a. New teleostean fishes from southern Germany and the systematic problems concerning the "pholidophoriforms". Paläontologische Zeitschrift 74(1/2): 113-143. 
Arratia G. 2000b. Phylogenetic relationships of Teleostei. Past and present. Estudios Oceanológicos 19: 19-51.

Arratia G. 2000c. Remarkable teleostean fishes from the Late Jurassic of southern Germany and their phylogenetic relationships. Mitteilungen aus dem Museum für Naturkunde, Berlin, Geowissenschaftliche, Reihe 3: 137-179.

Arratia G. 2001. The sister-group of Teleostei: Consensus and disagreements. Journal of Vertebrate Paleontology 21(4): 767773 ,

Arratia G. 2003. Catfish head skeleton. An overview. In: Arratia G, BG Kapoor, M Chardon \& R Diogo (eds). Catfishes, pp. 3-46. Science Publishers, Enfield.

Arratia G. 2004. Mesozoic halecostomes and the early radiation of teleosts. In: Arratia G \& A Tintori (eds). Mesozoic fishes 3 -Systematics, paleoenvironments and biodiversity, pp. 279315. Verlag Dr. F. Pfeil, München.

Arratia G. 2008a. The varasichthyids and other crossognathiform fishes, and the break-up of Pangaea. In: Cavin L, A Longbottom \& M Richter (eds). Fishes and the break-up of Pangaea. Special Publication 295: 71-92, Geological Society, London.

Arratia G. 2008b. Actinopterygian postcranial skeleton with special reference to the diversity of fin ray elements, and the problem of identifying homologies. In: Arratia G, H-P Schultze \& MVH Wilson (eds). Mesozoic fishes 4 -Homology and phylogeny, pp. 49-101. Verlag Dr. F. Pfeil, München.

Arratia G. 2009. Patterns of diversity of the actinopterygian fulcra. Acta Zoologica, Stockholm 90 (Suppl. 1): 220-235.

Arratia G \& T Bagarinao. 2009. Early ossification and development of the cranium and paired girdles of Chanos chanos (Teleostei, Gonorynchiformes). In: Grande T, FJ Poyato-Ariza \& R Diogo (eds). A comprehensive review of Gonorynchiformes and of Ostariophysan relationships, pp. 76-106. Scientific Publishers, Enfield.

Arratia G \& H-P Schultze. 1985. Late Jurassic teleosts (Actinopterygii, Pisces) from Northern Chile and Cuba. Palaeontographica A 189: 29-61.

Arratia G \& H-P Schultze. 1990. The urohyal: development and homology within osteichthyans. Journal of Morphology 203: $247-282$.

Arratia G \& H-P Schultze. 1991. Development and homology of the palatoquadrate in osteichthyans. Journal of Morphology 208: 1-81.

Arratia G \& H-P Schultze. 1992. Reevaluation of the caudal skeleton of certain actinopterygian fishes. III. Salmonidae. Homologization of caudal skeletal structures. Journal of Morphology 214: 187-249.

Arratia G \& H Tischlinger. 2010. The first record of Late Jurassic crossognathiform fishes from Europe and their phylogenetic importance for teleostean phylogeny. Fossil Record 13(2): 317-341.

Cavin L. 2001. Osteology and phylogenetic relationships of the teleost Goulmimichthys arambourgi Cavin, 1995, from the Upper Cretaceous of Goulmima, Morocco. Eclogae Geologicae Helvetiae 94: 509-535.
Cavin L \& D Grigorescu. 2005. A new Crossognathus (Actinopterygii, Teleostei) from the Lower Cretaceous of Romania with comments on Crossognathidae relationships. Geodiversitas 27: 5-16.

Cloutier R \& G Arratia. 2004. Early diversification of actinopterygians. In: Arratia G, MVH Wilson \& R Cloutier (eds). Recent advances in the origin and early radiation of vertebrates, pp. 217-270. Verlag Dr. F. Pfeil, München.

Cubbage CC \& PM Mabee. 1996. Development of the cranium and paired fins in the zebrafish Danio rerio (Ostariophysi, Cyprinidae). Journal of Morphology 229: 121-160.

De Pinna MCC. 1996. Teleostean monophyly. In: Stiassny MLJ, LR Parenti \& GD Johnson (eds). Interrelationships of fishes, pp.147-162. Academic Press, San Diego.

Engenman JM, N Aspinwall \& PM Mabee. 2009. Development of the pharyngeal arch skeleton in Catostomus commersonii (Teleostei: Cypriniformes). Journal of Morphology 270: 291305.

Faustino M \& DM Power. 2001. Osteological development of the viscerocranial skeleton in sea bream: alternative ossification strategies in teleost fish. Journal of Fish Biology 58: 537-572.

Fink SV \& WL Fink. 1981. Interrelationships of the ostariophysan fishes (Teleostei). Zoological Journal of the Linnean Society 72(4): 297-353.

Fink SV \& WL Fink. 1996. Interrelationships of ostariophysan fishes (Teleostei). In: Stiassny MLJ, LR Parenti \& GD Johnson (eds). Interrelationships of fishes, pp. 209-249. Academic Press, San Diego,

Forey LP. 1977. The osteology of Notelops Woodward, Rhacolepis Agassiz and Pachyrhizodus Dixon (Pisces: Teleostei). Bulletin of the British Museum of Natural History, Geology 28: 125-204.

Fujita K. 1990. The caudal skeleton of teleostean fishes, 897 pp. Tokai University Press, Tokyo.

Grande L \& W Bemis. 1998. A comprehensive phylogenetic study of amiid fishes (Amiidae) based on comparative skeletal anatomy. An empirical search for interconnected patterns of natural history. Journal of Vertebrate Paleontology 18 (Suppl 1), Memoir 4: 1-609.

Greenwood PH. 1973. Interrelationships of osteoglossomorphs. In: Greenwood PH, RS Miles \& C Patterson (eds). Interrelationships of fishes, pp. 307-332. Academic Press, London.

Hilton E. 2002. Osteology of the extant North American fishes of the genus Hiodon Lesueur, 1818 (Teleostei, Osteoglossomorpha: Hiodontiformes). Fieldiana, Zoology 100: $1-142$.

Hilton E. 2003. Comparative osteology and phylogenetic systematics of fossil and living bony-tongue fishes (Actinopterygii, Teleostei, Osteoglossomorpha). Zoological Journal of the Linnean Society, London 137: 1-100.

Inoue GJ, M Miya, K Tsukamoto \& M Nishida. 2001. A mitogenic perspective on the basal teleostean phylogeny: Resolving higher-level relationships with longer DNA 
sequences. Molecular Phylogenetics and Evolution 20(2): 275-285.

Johnson GD \& C Patterson. 1996. Relationships of lower euteleost fishes. In: Stiassny MLJ, LR Parenti \& GD Johnson (eds). Interrelationships of fishes, pp. 251-332. Academic Press, San Diego.

Jollie M. 1984. Development of the head skeleton and pectoral girdle in Esox. Journal of Morphology 147: 61-88.

Kohno H, R Ordonio-Aguilar, A Ohno \& Y Taki. 1996. Osteological development of the feeding apparatus in early stage larvae of the seabass, Lates calcarifer. Ichthyological Research 43: 1-9.

Koumoundouros G, P Divanach \& M Kentouri. 2000. Development of the skull in Dentex dentex (Osteichthyes: Sparidae). Marine Biology 136: 175-184.

Langille RM \& BK Hall. 1987. Development of the head skeleton of the Japanese medaka Oryzias latipes (Teleostei). Journal of Morphology 193: 135-158.

Lauder GV \& K Liem. 1993. The evolution and interrelationships of the actinopterygian fishes. Bulletin of the Museum of Comparative Zoology, Harvard University 150: 95-197.

Li C, G Lu \& G Ortí. 2008. Optimal data portioning and a test case for ray-finned fishes (Actinopterygii) based on ten nuclear loci. Systematic Biology 57(4): 519-539.

Nelson G. 1969. Gill arches and the phylogeny of fishes, with notes on the classification of vertebrates. Bulletin of the American Museum of Natural History 141: 477-552.

Nelson G. 1973a. Relationships of clupeomorphs, with remarks on the structure of the lower jaws in fishes. In: Greenwood PH, RS Miles \& C Patterson (eds). Interrelationships of fishes, pp. 333-349. Academic Press, London.

Nelson G. 1973b. Notes on the structure and relationships of certain Cretaceous and Eocene teleostean fishes. American Museum Novitates 2524: 1-31.

Nelson JS. 2006. Fishes of the world, 601 pp. John Wiley \& Sons, Hoboken.

Nybelin O. 1977. The polyural skeleton of Lepisosteus and certain other actinopterygians. Zoologica Scripta 6: 233-244.

Patterson C \& DE Rosen. 1977. Review of the ichthyodectiform and other Mesozoic teleost fishes and the theory and practice of classifying fossils. Bulletin of the American Museum of Natural History 158: 83-172.

Peng Z, S He, J Wang, W Wang \& R Diogo. 2006. Mitochondrial molecular clocks and the origin of the major otocephalan clades (Pisces: Teleostei): A new insight. Gene 370: 113-124.

Ridewood WG. 1905. On the cranial osteology of the fishes of the families Osteoglossidae, Pantodontidae, and Phractolaemidae. Zoological Journal of the Linnean Society, London 29: 252-282.
Rosen DE. 1973. Interrelationships of higher teleostean fishes. In: Greenwood PH, RS Miles \& C Patterson (eds). Interrelationships of fishes, pp. 397-513. Academic Press, London.

Rosen DE. 1974. Phylogeny and zoogeography of salmoniform fishes and relationships of Lepidogalaxias salamandroides. Bulletin of the American Museum of Natural History 153(2): 267-325.

Rosen DE. 1982. Teleostean interrelationships, morphological function and evolutionary inference. American Zoologist 22: 261-273.

Schultze H-P. 2008. Nomenclature and homologization of cranial bones in actinopterygians. In: Arratia G, H-P Schultze \& MVH Wilson (eds). Mesozoic fishes 4 -Homology and phylogeny, pp. 23-48. Verlag Dr. F. Pfeil, München.

Schultze H-P \& G Arratia. 1988. Reevaluation of the caudal skeleton of actinopterygian fishes. II. Hiodon, Elops and Albula. Journal of Morphology 195: 257-303.

Schultze H-P \& G Arratia. 1989. Reevaluation of the caudal skeleton of teleosts (Actinopterygii, Osteichthyes). Zoological Journal of the Linnean Society 97: 189-231.

Siebert DJ. 1987. Interrelationships among families of the order Cypriniformes (Teleostei). Unpublished PhD Dissertation, City University of New York, New York, 380 pp.

Stewart JD. 1999. A new genus of Saurodontidae (Teleostei: Ichthyodectiformes) from the Upper Cretaceous rocks of the Western Interior of North America. In: Arratia G \& H-P Schultze (eds). Mesozoic fishes 2 -Systematics and fossil record, pp. 335-360. Verlag Dr. F. Pfeil, München.

Taverne L. 1977. Ostéologie, phylogénèse et systématique des Téléostéens fossiles et actuels du super-ordre des Ostéoglossomorphes. Académie Royale de Belgique, Mémoires de la Classe des Sciences, Collection in- $8^{\circ}, 2^{\mathrm{e}}$ série, 42(3): 1-234.

Taverne L. 1989. Crossognathus Pictet, 1858 du Cretacé inférieur de l'Europe et systématique, paleozoogeographie et biologie des Crossognathiformes nov. ord. (Téléostéens) du Cretacé et du Tertiare. Palaeontographica A 207: 79-105.

Taverne L. 1998. Les ostéoglossomorphes marine de l’Éocene du Monte Bolca (Italie): Monopteros Volta, 1796, Thrissopterus Heckel, 1856 et Foreyichthys Taverne, 1979. Considérations sur la phylogénie des téléostéens ostéoglossomorphes. Studie e Ricerce sui Giacimenti Terziari di Bolca 7: 67-158.

Toombs HA \& AR Rixon. 1959. The use of acids in the preparation of vertebrate fossils. Curator 2: 304-312.

Vandewalle P, B Focant, F Huriaux \& M Chardon. 1992. Early development of the cephalic skeleton of Barbus barbus (Teleostei, Cyprinidae). Journal of Fish Biology 41: 43-62.

Wiley EO. 2008. Homology, identity and transformation. In: Arratia G, H-P Schultze \& MVH Wilson (eds). Mesozoic fishes 4 -Homology and phylogeny, pp. 9-21. Verlag Dr. F. Pfeil, München.

Recibido el 11 de agosto de 2009 y aceptado el 29 de abril de 2010 